\title{
THE ALPINI EFFECT: WHY THE US ARMY SHOULD TRAIN UNITS FOR MOUNTAIN WARFARE
}

A Monograph

by

MAJ Scott M. Safer

US Army

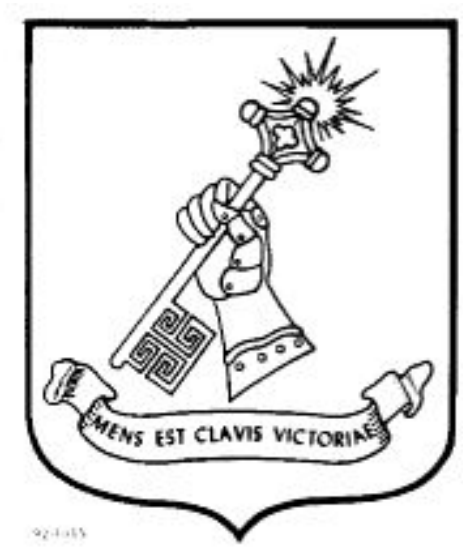

School of Advanced Military Studies

United States Army Command and General Staff College

Fort Leavenworth, Kansas

AY 2014-01 


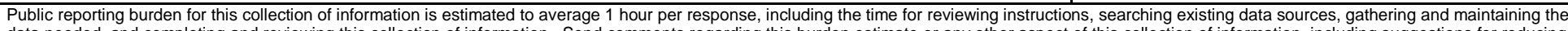

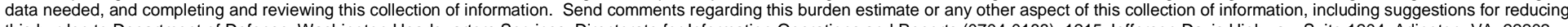

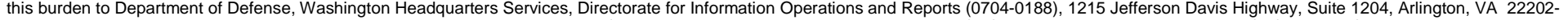

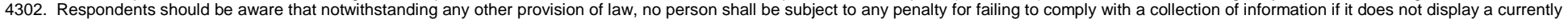
valid OMB control number. PLEASE DO NOT RETURN YOUR FORM TO THE ABOVE ADDRESS.

\begin{tabular}{l|l|l}
\hline 1. REPORT DATE (DD-MM-YYYY) & 2. REPORT TYPE & 3. DATES COVERED (FrOm - TO)
\end{tabular}

22 MAY $2014 \quad$ Master's Thesis

4. TITLE AND SUBTITLE

The Alpini Effect: Why the US Army Should Train For Mountain Warfare

JUN 2013-MAY 2014

5a. CONTRACT NUMBER

5b. GRANT NUMBER

5c. PROGRAM ELEMENT NUMBER

6. AUTHOR(S)

Major Scott M. Safer, US Army

5d. PROJECT NUMBER

5e. TASK NUMBER

5f. WORK UNIT NUMBER

7. PERFORMING ORGANIZATION NAME(S) AND ADDRESS(ES)

School of Advanced Military Studies

8. PERFORMING ORGANIZATION REPORT NUMBER

201 Reynolds Avenue

Ft. Leavenworth, KS 66027

9. SPONSORING I MONITORING AGENCY NAME(S) AND ADDRESS(ES)

U.S. Army Command and General Staff College

ATTN: ATZL-SWD-GD

Fort Leavenworth, KS 66027-2301

11. SPONSOR/MONITOR'S REPORT NUMBER(S)

\section{DISTRIBUTION I AVAILABILITY STATEMENT}

Approved for Public Release; Distribution Unlimited

13. SUPPLEMENTARY NOTES

\section{ABSTRACT}

The purpose of this monograph is to provide an analysis of why the US Army should designate active duty units to organize, equip, and train for mountain warfare. With over 35\% of land mass and $85 \%$ of land borders in the world categorized as mountainous, there is a likelihood that the US Army will be fighting in mountainous terrain in future conflicts. Mountain warfare is complex and has many interdependent factors found in its peculiar characteristics and operational effects, more so than other specialized forms of warfare in jungle and desert terrain. These peculiar characteristics of mountainous terrain include the effects of weather, effects on personnel, and effects on weapons and equipment. The operational effects of mountainous terrain limit operational reach, constrain lines of operations, and complicate mission command. The combination of complexity, peculiar characteristics, and operational effects requires a significant amount of time for unit leadership and soldiers to learn in order to operate and fight effectively in a mountainous environment as a combined arms team. This was evidenced by the success of the US Army's $10^{\text {th }}$ Mountain Division in Italy at Riva Ridge in 1945 and the failure of the Indian $4^{\text {th }}$ Infantry Division against the People's Liberation Army of China in northeastern India in 1962.

\section{SUBJECT TERMS}

Mountain warfare, jungle warfare, desert warfare, operational effects, $10^{\text {th }}$ Mountain Division, Indian Army

\begin{tabular}{|c|c|c|c|c|c|}
\hline 16. SECURITI & LASSIFICATION & & 17. LIMITATION & 18. NUMBER & 19a. NAME OF RESPONSIBLE PERSON \\
\hline a. REPORT & b. ABSTRACT & c. THIS PAGE & & & 19b. TELEPHONE NUMBER (include area code) \\
\hline (U) & (U) & (U) & (U) & 51 & \\
\hline
\end{tabular}




\section{MONOGRAPH APPROVAL PAGE}

Name of Candidate: MAJ Scott M. Safer

Monograph Title: The Alpini Effect: Why the US Army Should Train Units for Mountain Warfare

Approved by:

Monograph Director

Peter J. Schifferle, Ph.D.

Seminar Leader

Christopher T. Drew, COL

, Director, School of Advanced Military Studies

Hank A. Arnold III, COL

Accepted this _22 ${ }^{\text {nd }}$ - day of _May 2014_by:

Robert F. Baumann, Ph. D.

, Director, Graduate Degree Programs

The opinions and conclusions expressed herein are those of the student author and do not necessarily represent the views of the US Army Command and General Staff College or any other governmental agency. (References to this study should include the foregoing statement.) 


\begin{abstract}
THE ALPINI EFFECT: WHY THE US ARMY SHOULD TRAIN UNITS FOR MOUNTAIN WARFARE, by MAJ Scott M. Safer, 51 pages.
\end{abstract}

The purpose of this monograph is to provide an analysis of why the US Army should designate active duty units to organize, equip, and train for mountain warfare. With over $35 \%$ of land mass and $85 \%$ of land borders in the world categorized as mountainous, there is a likelihood that the US Army will be fighting in mountainous terrain in future conflicts. Mountain warfare is complex and has many interdependent factors found in its peculiar characteristics and operational effects, more so than other specialized forms of warfare in jungle and desert terrain. These peculiar characteristics of mountainous terrain include the effects of weather, effects on personnel, and effects on weapons and equipment. The operational effects of mountainous terrain limit operational reach, constrain lines of operations, and complicate mission command. The combination of complexity, peculiar characteristics, and operational effects requires a significant amount of time for unit leadership and soldiers to learn in order to operate and fight effectively in a mountainous environment as a combined arms team. This was evidenced by the success of the US Army's $10^{\text {th }}$ Mountain Division in Italy at Riva Ridge in 1945 and the failure of the Indian $4^{\text {th }}$ Infantry Division against the People’s Liberation Army of China in northeastern India in 1962. 


\section{TABLE OF CONTENTS}

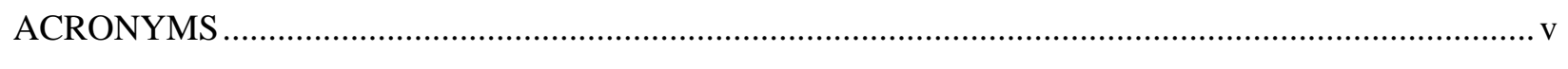

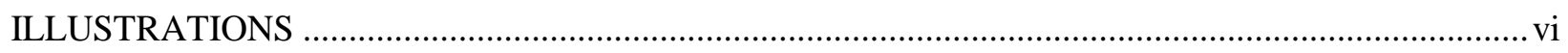

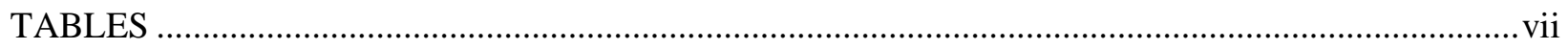

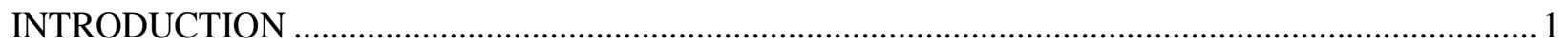

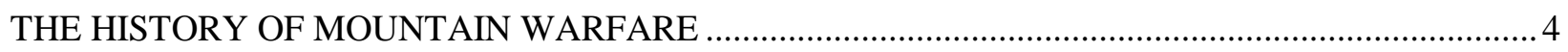

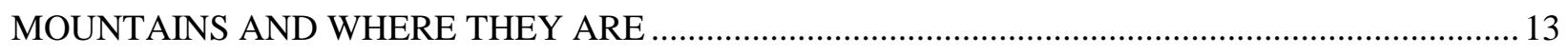

PECULIAR CHARACTERISTICS OF MOUNTAINOUS TERRAIN............................................. 17

OPERATIONAL EFFECTS OF MILITARY OPERATIONS IN MOUNTAINOUS TERRAIN ............ 22

TRAINED AND UNTRAINED UNITS IN MOUNTAIN WARFARE ........................................... 28

Case Study \#1: Mountain Warfare Success - Operation ENCORE .............................................. 29

Case Study \#2: Mountain Warfare Failure - Battle in the Kameng............................................... 36

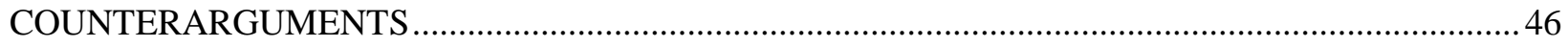

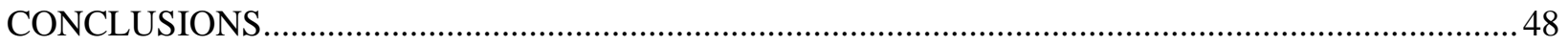

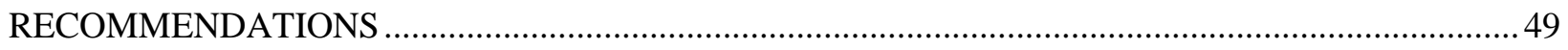

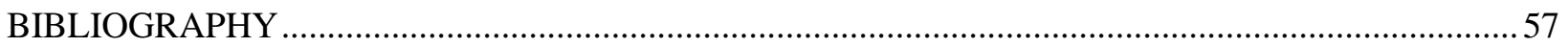




\section{ACRONYMS}

\begin{tabular}{|c|c|}
\hline ADRP & Army Doctrine Reference Publication \\
\hline AMS & Acute Mountain Sickness \\
\hline AMWS & Army Mountain Warfare School \\
\hline AR & Army Regulation \\
\hline BCT & Brigade Combat Team \\
\hline $\mathrm{BEF}$ & Brazilian Expeditionary Force \\
\hline $\mathrm{COP}$ & Combat Outpost \\
\hline FM & Field Manual \\
\hline HACE & High Altitude Cerebral Edema \\
\hline HAPE & High Altitude Pulmonary Edema \\
\hline MOA & Minute of Angle \\
\hline MTN IN & Mountain Infantry \\
\hline MTOE & Modified Table of Organization and Equipment \\
\hline N.E.F.A. & North-East Frontier Agency \\
\hline NGA & National Geospatial-Intelligence Agency \\
\hline PLA & People’s Liberation Army \\
\hline TC & Training Circular \\
\hline TM & Technical Manual \\
\hline UN & United Nations \\
\hline USSOCOM & United States Special Operations Command \\
\hline
\end{tabular}




\section{ILLUSTRATIONS}

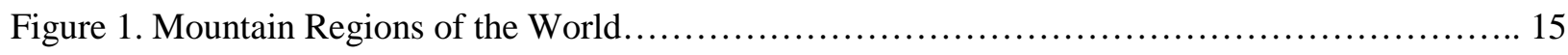

Figure 2. Map of Central Italy and Area of Operations for Operation ENCORE...................... 32

Figure 3. Operation ENCORE - Riva Ridge \& Monte Belvedere to Torraccia.........................34

Figure 4. Geographical Overview of 1962 Indian - China Frontier................................38

Figure 5. N.E.F.A. and the Kameng Frontier - 1962 Indian-China Crisis........................... 41 


\section{TABLES}

Table 1: United States Army Doctrine for Training Units for Mountain Warfare since 1941............53

Table 2: Conclusions from Research about Trained Units in Mountain Warfare since $1944 \ldots . . . . . . . . . .54$

Table 3: Country Borders with and without Mountainous Borders...................................55

Table 4: Comparison of Weather Effects...................................................56 


\section{INTRODUCTION}

An army which may have to fight anywhere in the world must have an important part of its major units especially organized, trained and equipped for fighting in the mountains and in winter. The Army and equipment must be on hand and the troops fully conditioned, for such units cannot be improvised hurriedly from line divisions ${ }^{1}$

- Lieutenant Colonel Norman E Fiske, 1941

Italy formed the Alpini in 1872 after they realized the need for specially trained mountain warfare military units. The Italians came to this conclusion after realizing that they could not mobilize and train troops fast enough to defend their mountainous territories effectively from an invading country along their northern border. ${ }^{2}$ Sixty-six years later in November 1941, the US Army also recognized the need for units trained in mountain warfare and two years later in 1943 organized the $10^{\text {th }}$ Mountain Division. In February 1945, after 16 months of robust training in Colorado, the $10^{\text {th }}$ Mountain Division used its mountain warfare skills during the Second World War in northern Italy to conduct successful mountain operations and defeat the German defenses at Riva Ridge. ${ }^{3}$ Although, the US Army had a successful experience with an infantry division trained for mountain operations during the Second World War, the US Army mountain warfare doctrine has devolved from having specialized and trained units for mountain operations to using general purpose units that train mountain warfare only when assigned missions in mountainous

${ }^{1}$ Thomas Govan, Training for Mountain and Winter Warfare: Study Number 23 (Washington, DC: HQ Army Ground Forces, 1946), 5. This quote is from the August 1941 report of the US military attaché in Italy who wrote on observations of Italy's disastrous mountain operations during its 1941 Spring Offensive against the Greeks in Greek-occupied Albania. Thomas Govan's Study Number 23 provides reasons for and actions taken by the US War Department prior to and during the Second World War to train and equip units and soldiers for winter and mountain warfare. Govan utilized and researched numerous internal War Department personal correspondences and internal memorandums from 1941-1944 in order to complete his study.

${ }^{2}$ Victor Emmanuel II, Royal Decree 1056 (Naples: Kingdom of Italy, 15 October 1872), 1; Govan, Training for Mountain and Winter Warfare: Study Number 23, 11. The royal decree by King Emmanuel II of Italy established fifteen companies of mountain units called Alpini to guard the Italian border.

${ }^{3}$ Govan, Training for Mountain and Winter Warfare: Study Number 23, 6-7; Ernest Fisher Jr., US Army in WWII Mediterranean Theater of Operations: Cassino to the Alps (Washington, DC: Center of Military History, 1977), 424-428. Averaging 3,800 feet (approximately 1,200 meters) in height, Riva Ridge consisted of a series of mountain peaks and ridges in the Apennine Mountain range in northern Italy. 
terrain. ${ }^{4}$ A military’s cognitive intuition that it needs to have specially trained units in mountain warfare (experienced by both the Italian and American militaries) is called the Alpini Effect. ${ }^{5}$

The US Army needs to experience a new Alpini Effect and designate active duty units to organize, train, and equip for mountain warfare as an operational capability. By having specialized active duty conventional units trained in mountain warfare, the US Army can provide strategic options to combatant commanders for offensive and defensive operations in a theater of war.

The US Army should designate active duty units to organize, train, and equip for mountain warfare because mountainous terrain has peculiar characteristics that take a significant amount of time and experience for leaders and soldiers to understand. Additionally, mountainous terrain affects military operations and military units trained in mountain warfare are more successful than untrained units in this environment. The peculiar characteristics of mountainous terrain on operations are the effects of weather, effects on personnel, and effects on weapons and equipment. Mountainous terrain affects operations differently than other terrain because it limits operational reach, restricts lines of operation, and complicates mission command. ${ }^{6}$ Military units trained in mountain warfare are more successful than untrained military units because they have

\footnotetext{
${ }^{4}$ Department of the Army, Field Manual 3-97.6, Mountain Operations (Washington, DC: Department of the Army, 2000), v. As of 2014, the active US Army does not actively train units for mountain warfare. The only unit in the US Army National Guard that trains and is equipped for mountain warfare is the $86^{\text {th }}$ Infantry Brigade Combat Team (Mountain), headquartered in Vermont. Field Manual 397.6 is the US Army's published doctrine on mountain operations. It was first published in 1944 as Field Manual 70-10, renumbered Field Manual 90-6 in 1959 and Field Manual 3-97.6 in 2000. It has been republished five times $(1947,1959,1964,1980$, and 2000) since the first issue in 1944.

${ }^{5}$ The Alpini Effect is an original concept presented by the author.

${ }^{6}$ Department of the Army, Army Doctrine Reference Publication 3-0, Unified Land Operations (Washington, DC: HQ Department of the Army, 2012) 3-2 and 4-5. Operational reach is the distance and duration across which a force can successfully employ military capabilities. Line of operation is a line that defines the directional orientation of a force in time and space in relation to the enemy and that links the force with its base of operations and objectives, which connects a series of decisive points that lead to control of a geographic or force-oriented objective. Mission command is the related tasks and systems that develop and integrate those activities enabling a commander to balance the art of command and the science of control in order to integrate the other war fighting functions (Mission Command, Movement and Maneuver, Fires, Sustainment, Protection, and Intelligence).
} 
the specialized technical skills and equipment to be able operate in an austere mountainous environment, leaders understand how to plan for mountainous terrain, and mountain units have better cohesion and esprit de corps from arduous specialized training.

The methodology used is to first build a foundational understanding of mountain warfare by explaining how and why mountain warfare developed historically, the likelihood of combat occurring in mountainous terrain, the peculiar characteristics of mountains and the operational effects on military operations in mountainous terrain. The peculiar characteristics of mountainous terrain are described separately from the operational effects of mountainous terrain, because the characteristics are important to tactical considerations. If these peculiar characteristics are disregarded or are unfamiliar to leaders or soldiers, an increased risk of mission failure will occur.

With this foundational understanding of mountain warfare, two case studies are compared in order to illustrate the importance of units being trained in mountain warfare. The first case study is of the US Army $10^{\text {th }}$ Mountain Division, trained in mountain warfare, which was successful in the Mediterranean theater of operations in Italy during the Second World War in 1945. The second case study is of the Indian $4^{\text {th }}$ Infantry Division, untrained in mountain warfare, which was unsuccessful during the Chinese-Indian conflict in 1962. Each case study was chosen because each case occurred in a different area of the world, at different times and in different conflicts, which gives multiple contexts for demonstrating the importance of unit mountain warfare training. The closing sections address two counterarguments against having mountain warfare trained units, provide a final conclusion, and make recommendations of how the US Army should develop and establish training for units organized to conduct mountain warfare. $^{7}$

\footnotetext{
${ }^{7}$ Two main counterarguments are addressed. First, the US Army does not need to have mountain warfare trained units, because the US Army has been fighting successfully in the mountainous country of Afghanistan since 2001 with general purpose units. Second, if the US Army were to organize a unit specialized for mountain warfare, the US Army needs to also organize units for jungle and desert terrain, which it does not have adequate resources to implement.
} 
Key terms used in this monograph that are not formally defined by the Department of Defense or US Army are mountaineering, mountain warfare, and mountain operations.

Mountaineering is the application of techniques by a military or civilian individual to complete a task in order to operate in mountainous terrain. Mountain warfare is the combined arms application of fire and maneuver by a military unit to conduct tactical actions in mountainous terrain or at high altitudes. ${ }^{8}$ Mountain operations are when a trained or untrained unit or group conducts activity in mountainous terrain.

\section{THE HISTORY OF MOUNTAIN WARFARE}

The history of mountain warfare underscores the importance of mountain warfare, and provides insight into its principles and theories, and realization of the consequences when the special challenges of mountainous terrain are discounted rather than respected. The history of mountain warfare can be divided into four distinct eras: Pre-Napoleon (218 B.C. - 1798), French Influence (1798 - 1870), Alpini Effect (1872 - 1945), and Post Second World War (1945 present). The Pre-Napoleon era began with the Carthaginian advance across the Alps against the Roman Empire and ends with the French annexation of Switzerland during the 2d War of Coalition. ${ }^{9}$ The era of French Influence began with the French march across Switzerland and ends with the reunification of Italy. The Alpini Effect era began with the reunification of Italy

\footnotetext{
${ }^{8}$ Edwin Clarke, "Enhancing the US Special Operations Mountaineering Program" (Master's Thesis, Naval Post Graduate School, Monterrey, CA, June 2012), 20. High altitude areas that are not necessarily mountainous can be found in high altitude plateaus like the Andean altiplano, averaging 12,000 feet (approximately 3,700 meters), and the Tibetan plateau averaging 14,700 feet (approximately 4,500 meters). Clarke's thesis examines the current standing mountain warfare capability in US Special Operations, the conventional US military, and select international special operations units. It also conducts a comparative analysis of the effectiveness and efficiency of the United States Special Operations Command (USSOCOM) mountaineering program with respect to these other mountaineering programs.

${ }^{9}$ David G. Chandler, Napoleon's Marshals (New York: Macmillan, 1987), 1. The Napoleonic Wars from 1798 to 1812 consisted of seven distinct conflicts where France fought against different coalitions that sought to neutralize French influence and power in Europe. Each of these conflicts is identified as a War of Coalition. From 1798-1802, the 2d War of Coalition was fought between France and the coalition of the Habsburg monarchy (Austria) and the Russian Empire. France made it the deliberate policy to annex Switzerland in order to secure its eastern borders. The Army of Helvetica was a name given to the French revolutionary Army operating in Switzerland from 1798-1799. Helvetica is Latin for Switzerland.
} 
and ended with the deactivation of $10^{\text {th }}$ Mountain Division at the end of $1945 .{ }^{10}$ The Post Second World War era began with the deactivation of the $10^{\text {th }}$ Mountain Division and continues through present day. The concept of mountain warfare has progressed during each of these eras, but not until the mid $19^{\text {th }}$ century did western military theorists recognize that mountain warfare was a specialized form of warfare that needed to be seriously considered due to its extended order of battle, the use of infantry armed primarily with firearms, and the rise of French military power. ${ }^{11}$ The US Army mountain warfare doctrine of 2014 has changed since 1945 from having specialized units trained in mountain warfare to simply using general purpose units that are trained when necessary.

The Pre-Napoleon era began with the Carthaginian General Hannibal Barca’s advance through the Alps against the Roman Empire in 218 B.C. during the $2^{\text {nd }}$ Punic War. ${ }^{12}$ This was the first recorded instance of sustained mountain operations and mountain warfare in western literature. General Hannibal marched with his army of over 50,000 soldiers, 9,000 cavalry, and a contingent of elephants from the Spanish Ebro river over the Pyrenees, across Gaul (present day France) to the Rhone River and over the Alps into the Po River valley (present day northern Italy). Although the exact route of his march is not exactly known, his army not only had to travel through mountains, but fight in mountains against hostile tribes to secure a safe march

${ }^{10}$ The $10^{\text {th }}$ Mountain Division was originally organized as the $10^{\text {th }}$ Light Division (Alpine) in 1943 , but was redesignated the $10^{\text {th }}$ Mountain Division in 1944. For the purpose of continuity within this monograph all references to the $10^{\text {th }}$ Light Division (Alpine) are known as the $10^{\text {th }}$ Mountain Division. The $10^{\text {th }}$ Mountain Division was deactivated at the end of 1945 , but has been reactivated in numerous capacities since, to include most recently as a light infantry division.

${ }^{11}$ Carl von Clausewitz, On War, trans. Michael Howard and Peter Paret (Princeton, NJ: Princeton University Press, 1976), 418. Clausewitz adds that with the increase of size in armies after the Thirty Years War (1618-1648), mountainous terrain increased in defensive significance as battle lines extended and defensive actions became defensive unions between defender and terrain to stop the attacker.

${ }^{12}$ General Hannibal Barca is known simply as General Hannibal and is referenced as this throughout the monograph. Although there are other accounts of conflicts in history that involve mountainous terrain, such as the Spartans at Thermopylae (480 B.C.) or the Roman siege against the Jews at Masada (80 B.C.), General Hannibal's march across the Alps is used as a benchmark as it was the first sustained campaign with an army across mountainous terrain. 
route for his army. Hannibal's army did not specifically train for mountain warfare, which contributed to the loss of almost two-thirds of its combat power from disease and cold during its march over the Pyrenees and Alps. ${ }^{13}$

Switzerland quickly became a conflict zone in the early Middle Ages as feudal states and nations fought over key terrain and resources. Conflicts in mountainous areas culminated in the successful Swiss defense against the Austrians at the Battles of Morgarten and Sembach in the $14^{\text {th }}$ Century and again against the Kingdom of Burgundy at the Battles of Murten and Granson in the $15^{\text {th }}$ Century. These victories brought the sense to western European rulers that it was too difficult to win battles in mountainous terrain. This was due to the fact that lightly-armed peasants in mountainous terrain were outmaneuvering and defeating slow-moving armies, who were burdened with heavy armor and cannons and forced to move on foot in rugged terrain due to lack of roads. ${ }^{14}$ This changed however with the extended order of battle, the use of infantry armed primarily with firearms, and the rise of French military power.

The French Influence era began with the rise of French power when the French Army of Helvetica led by French General André Masséna, during the War of the $2^{\text {nd }}$ Coalition, successfully marched across Switzerland. The successful mountain operations in Switzerland were the catalyst that stimulated thinking about mountain warfare by two mid- $19^{\text {th }}$ century European military theorists; the Prussian General Carl von Clausewitz and French General

${ }^{13}$ Alfred Church, The Story of Nations: Carthage (London: G.P. Putnam's Sons, 1895), 185-194. Alfred Church provides a chronological narrative from the late 1800s of Carthage including General Hannibal's operations across the Alps in his attempt to defeat Rome. Church's narrative lacks specifics. However, due to the time elapsed since the occurrence of the events, the lack of detail is understandable.

\footnotetext{
${ }^{14}$ Frederick Engels "Marx and Engels Collected Works," Marxist Internet Archive, http://www.marxists.org/archive/marx/works/cw/ (accessed November 26, 2013). Frederick Engels wrote in an 1857 New York Times newspaper article titled Mountain Warfare Past and Present, and two weeks later an unpublished article at the request of Karl Marx. These articles were triggered by the Neuchâtel conflict and plans for the invasion of Switzerland by Prussia. Prussia's plans were widely discussed in the press and the Swiss government made concessions to Prussia to resolve the conflict. Engels discussion on mountain warfare was influenced by the French Army's success during the 2d War of the Coalition (17981802) in the mountainous country of Switzerland, which was previously thought to be unconquerable.
} 
Antoine Henri Jomini. ${ }^{15}$ Clausewitz concluded that mountainous terrain could only be decisive for an attacker, has an effect on other surrounding terrain if occupied, is effective as a strategic barrier, and restricts logistical operations. ${ }^{16}$ Jomini determined that the effect of mountains on military operations is relative to the surrounding terrain, the most strategic points within a mountainous area is at the junction of valleys, it is difficult to have a decisive battle defensively in mountainous terrain due to the inability to concentrate forces, and mountainous areas are advantageous for the defender in wars of national survival due to resistance of the populace against the attacker on difficult terrain. ${ }^{17}$

The Alpini Effect era began with the reunification of the Italian peninsula by the Sardinianled Kingdom of Italy. By 1860 only four states or nations held power in the Italian peninsula; the Austrian Empire, the Papacy, the Kingdom of Piedmont-Sardinia, and the Kingdom of the Two Sicilies. ${ }^{18}$ The Kingdom of Italy was established in 1861 by the Sardinians after the defeat of Sicilian forces. With the rise of Prussian power in Europe, the Austrians were weakened in 1866 during the Austro-Prussian war. This allowed Italian forces to consolidate Austrian-held territory in Venetia under Italian control. The Papacy fell under Italian control when French troops, supporting the Papacy in Rome, were called back to France in response to the Prussian invasion

${ }^{15}$ Jomini was originally born in Switzerland and served in both the French and Russian military, but for the purpose of this monograph is referred to in the French context.

${ }^{16}$ Clausewitz, On War, 423. Clausewitz concludes that mountainous terrain can only provide a decisive advantage to the attacker, because the attacker can choose the time and place of attacking the defender, who cannot easily maneuver due to restricted terrain. Occupying a mountainous area affects other areas around it because the occupier can observe and influence the plains around it. Mountainous areas present a strategic barrier due to the effects it has on military unit maneuverability and lines of communication.

${ }^{17}$ Antoine Jomini, The Art of War, trans. G. H. Mendell and W. P. Craighill (Philadelphia: J. B. Lippincott and Company, 1862), 146-153.

${ }^{18}$ Using the current country borders of Italy as a reference; the Austrian Empire controlled the territory of Venetia in northeastern Italy, the Papacy held territory in central Italy centered on Rome, the Kingdom of Piedmont-Sardinia held the island of Sardinia and northwestern Italy centered on the city of Turin, and the Kingdom of Two Sicilies was located in southern Italy and the island of Sicily. 
of $1870{ }^{19}$ With the reunification of the Italian peninsula, the Kingdom of Italy became a geopolitical national power in Europe, and needed to defend its mountainous borders.

Military units trained in mountain warfare appeared for the first time in Italy in 1872 with the formation of Alpini infantry units. The Alpini were established in order to defend the mountainous borders of Italy. Captain Giuseppe Perrucchetti published an article in the May 1872 edition of the Italian Military Review (Rivista Militare) based on observations from his reconnaissance of the military topography in the Italian Alps. He proposed assigning the territorial defense of Italian mountain borders to units formed from locally recruited soldiers and trained in mountain warfare. Perrucchetti recognized that Italy could not mobilize troops fast enough to defend the mountainous border territories from an external threat and if soldiers from other parts of Italy were used in mountainous terrain they would "have very little practical knowledge of the ground, and are very little adapted for mountain warfare.”20 The concept of infantry forces trained in mountain combat was born, and the Kingdom of Italy established the Italian Alpini on 15 October $1872 .^{21}$

During the Alpini Effect era, mountain warfare was formally inculcated into militaries after the concept of having troops trained in mountain warfare took hold in Western European countries. After the Italian Alpini formed, the French established mountain trained units (Chasseurs Alpins) on 24 December 1888 in response to the newly perceived threat along the

\footnotetext{
${ }^{19}$ William Hunt, History of Italy (New York City: Henry Holt and Company, 1875), 241-61; Orsi Pietro, The Story of the Nations: Modern Italy: 1748-1898 (New York City: G. P. Putnam's Sons, 1900), 246-316. Venetia was a territory controlled by the Austrian Habsburg Empire in present day north eastern Italy centered on the city of Venice.

${ }^{20}$ G. Bourbon Del Monte, “The Origin of Our Alpine Troops,” The United Service Magazine 17 (April to September 1898): 162-72. Although there were other Italian officers that contributed to the idea of forming mountain trained units, Captain Perrucchetti was the first person to develop and propose this idea. Bourbon Del Monte was a lieutenant in the Italian $6^{\text {th }}$ Alpine Regiment and describes the influences on and reasons why Captain Perruchetti developed the concept of organizing units for mountain warfare.

${ }^{21}$ Emmanuel II, Royal Decree 1056, 1.
} 
Italian border. ${ }^{22}$ Other European nations continued to form mountain trained infantry units prior to and during the First World War, where they were utilized in multiple theaters of operations. However, the ability to fight in mountainous terrain was most critical on the Italian Front, where Italy defended against the Austrians in northeastern Italy. Along this mountainous front the Italian military prevailed and facilitated the surrender of Austria on 3 Nov $1918 .^{23}$

The Alpini Effect during the interwar years between the First and Second World Wars began to take hold at the US Army’s Command and General Staff School in literary research as students analyzed battles from the Italian front during the First World War. MAJ Homer Brown experienced the Alpini Effect with his 1934 analytical research on the Battle of Caporetto on the Italian Front during the First World War, when he stated "In mountain warfare only troops well trained in this form of fighting can hope to succeed.”24 With increasing military actions across the world in the late 1930s, the US military realized that it needed to have trained units for mountain operations.

Prior to the United States' involvement in the Second World War, the US military leadership decided to organize and train an infantry division for mountain combat due to the confluence of influential events. ${ }^{25}$ These events were the success and failure of European

\footnotetext{
${ }^{22}$ C. de Freycinet, Bulletin 1208, Number 20037 - Loi Qui Modife L'organisation Des Bataillons de Chasseurs á Pied (Paris: France, 1888). This was the official order that established French mountain troops.

${ }^{23}$ Heinz Lichem, Gebirgskrieg 1915-1918: Ortler, Adamello, Gardasee (n.p.: Athesia, 1980), 50. The Italian Front in the First World War refers to a series of battles in northeastern Italy from 1915-1918 between Italy, Austria, and Germany and their respective mountain infantry units (Alpini, Kaiserjäger, and Alpenkorps). The battles were fought on mountain tops and ridges in harsh terrain. Italy ultimately prevailed and forced Austria to surrender after the Battle of Vittorio-Veneto in turn causing Germany to lose a critical ally and contribute to the reasons for Germany's surrender in the First World War. Interviews of German and Austrian troops that fought in the First World War by Heinz Lichem attest to the performance and fighting capability of the Alpini on the mountainous Italian Front.

${ }^{24}$ Homer Brown, "Operations On the Italian Front in 1917, Paying Particular Attention to the Caporetto Disaster and the Retreat to the Piave" (Historical Research, Command and General Staff School, Fort Leavenworth, KS, 1934).

${ }^{25}$ Marice Matloff, Command Decisions: The 90-Division Gamble (Washington, DC: Center of Military History, 1960), 365-80. This was a significant decision and calculated risk by the Army Chief of Staff George Marshall as he decided to limit the amount of Army Divisions to 90 and organize one division
} 
military operations in the beginning stages of the Second World War, a perceived threat of the American homeland, and pressure from civilian organizations. The War Department Intelligence division attributed the success of the German Wehrmacht in the Balkans to units specifically trained for mountain combat and the British failure to defend Norway due to the lack of mountain warfare training. Additionally, the US military attaché in Italy attributed the failure of Italian (non Alpini) units in Greek-occupied Albania to being unprepared and unequipped for mountain warfare. The US perceived a threat against the homeland from reports from Swiss and German informants that the German Wehrmacht was training special mountain troops for use in Alaska and in the Rockies. ${ }^{26}$ The informants explained that one of the principal objectives of the German campaign in the Soviet Union was the establishment of a bridge to Japan and the Vladivostockeastern Siberian area from which war could be carried easily to the United States through Alaska. Lastly, civilian pressure on the War Department to train and specialize military units in mountain and winter warfare came from Minnie Dole, the president of the National Ski Patrol. These reports and domestic pressures caused the War Plans Division to recommend to the Army Chief of Staff General George Marshall to form at least one infantry division trained in mountain warfare to be able to undertake any type of operation and be a strategic reserve. As a result, the US Army organized and trained the $10^{\text {th }}$ Mountain Division for mountain warfare in the Colorado

for mountain warfare. Initial projections for required number of divisions for the Second World War by the War Department were at least 200 divisions. Marshall wanted to support a war with a concentrated effort and not a war of attrition or peripheral action. He also realized that an increase in the number of Army divisions would undermine the United States’ ability to provide able-bodied workers for its industrial capacity.

${ }^{26}$ Hope Hamilton, Sacrifice On the Steppe: The Italian Alpine Corps in the Stalingrad Campaign, 1942-1943 (Philadelphia, PA: Casemate, 2011). A interesting counterpoint on how the Germans used the Italian Alpini mountain troops, was seen along the non-mountainous eastern front. After the invasion of the Soviet Union by Germany, the Italians sent a 200,000 man expeditionary force (60,000 Alpini) to the eastern front to help the Germans. By the winter of 1942, the Alpini were deployed along a 440 mile (approximately 270 kilometer) front on the Don River in western Soviet Union and not in the Caucasus Mountains as the Italians had envisioned. The Alpini troops were eventually encircled by the Russian tank armies, but the Italian Alpini were one of the only Axis units able to breakout and make it back to German lines. The Alpini's tenacious fighting ability, even in a non-mountainous environment, can be attributed to their unit esprit-de-corps, physical endurance, and comradery forged during training in mountainous terrain. 
Rocky Mountains. The $10^{\text {th }}$ Mountain Division deployed to combat in 1944 to the Mediterranean theater of operations in Italy. ${ }^{27}$ After the Second World War the United States demobilized and inactivated the $10^{\text {th }}$ Mountain Division and on 15 November 1945 lost its operational capability for mountain warfare. ${ }^{28}$

In the Post-Second World War era, the United States' first published mountain warfare doctrine contrasts differently from today’s doctrine even though mid-level military leaders have realized the importance of having trained units in mountain warfare. While the $10^{\text {th }}$ Mountain Division was training in Colorado in 1944, the US Army published its first organizational doctrine on mountain warfare as it stated, "The organization of the standard infantry division is suitable for operations in low mountain terrain...complete reorganization and specialized technical training as well as the use of special clothing and equipment will be required for operations in alpine terrain." ${ }^{29}$ US Army doctrine slowly changed to using general purpose infantry units for mountain warfare as explained in the 1964 version of Field Manual 31-72 Mountain Operations, “The airborne and the air assault division because of training and light

${ }^{27}$ Govan, Training for Mountain and Winter Warfare: Study Number 23, 5-12: Peter Shelton, Climb to Conquer: The Untold Story of World War II's 10th Mountain Division Ski Troops (New York: Scribner, 2003), 14-17. Minnie Dole realized that in 1940 with the conflict in Europe increasing that the US had no troops trained and equipped for mountains or cold weather. With the previous conflicts being in Panama and the Philippines, as well as almost all of the training facilities in the deep South, Hawaii, or Panama, the US Army was in effect a tropical army. It is estimated that Dole wrote over 2,000 letters to officials in Washington, DC as well as had a meeting with the Army Chief of Staff General George Marshall in order to convince the Army to organize and equip a mountain division as he envisioned that warfare in mountainous terrain was imminent. Once the decision was made to form a mountain trained division, the $10^{\text {th }}$ Mountain Division was organized, trained, and equipped by instructors at the US Mountain Training Center at Camp Carson, Colorado. The US Mountain Training Center was formed in early 1943 with soldiers that had expertise in mountaineering and skiing.

${ }^{28}$ "History of 10th Mountain Division," Fort Drum Official Website, http://www.drum.army.mil/ AboutFortDrum/Pages/hist_10thMountainHistory_lv3.aspx (accessed February 14, 2013). This was part of the United States' post Second World War reduction in force across the military

${ }^{29}$ US Armed Forces War Department, Field Manual 70-10, Mountain Operations (Washington, DC: United States Forces War Department, 1944), 1. Field Manual 70-10 (1944) describes alpine terrain as high, barren mountains with little or no vegetation, most of which is above the tree line and can be equated to Level III operational terrain as described in Field Manual 3-97.6 Mountain Operations (2000) and in later sections 
equipment are ideally suited for mountain operations.” (See Table 1$)^{30}$ Today the US Army mountain warfare doctrine states that Army units do not routinely train for operations in mountainous environments and units should conduct mountain training if assigned an operation in mountainous terrain. In contrast, US military leader and foreign officer conclusions based on research and personal experiences have contradicted US Army doctrine nine times since 1944 in regards to organizing and training units for mountain warfare. Pakistani Major Muhammad Asim Malik concluded simply in his 2003 Master’s Thesis, “Maintain operationally ready mountain troops.” (See Table 2) ${ }^{31}$

Additionally, in the Post-Second World War era, the US Army reactivated the $10^{\text {th }}$ Mountain Division (Light) at Fort Drum, NY in 1984 as part of the US Army's organization of four light infantry divisions. These infantry divisions were designed to be general purpose units to fight anywhere, anytime and be able to quickly deploy to reinforce heavy divisions in Western Europe or the Far East. ${ }^{32}$ However, the $10^{\text {th }}$ Mountain Division (Light) was not envisioned to be specifically trained in mountain warfare and the 'Mountain' designation was only an indicator of heritage not practicality. Since the reactivation of the $10^{\text {th }}$ Mountain Division (Light), the US Army has maintained the philosophy of having general purpose units through two US Army force transformations, because light infantry units are seen as rapid deployable units and not necessarily

\footnotetext{
${ }^{30}$ Department of the Army, Field Manual 31-72, Mountain Operations (Washington, DC: Department of the Army, 1964), 2. Table 2 depicts the evolution of organizational doctrine for units trained in mountain warfare from 1941 through 2000.

${ }^{31}$ Muhammad Malik, "Mountain Warfare: The Need for Specialist Training" (Master Thesis, Command and General Staff College, Fort Leavenworth, KS, 2003). This table of conclusions was developed by researching the Combined Arms Library Database and querying their chief research librarian for all research projects, studies, and monographs relating to mountain warfare. Specific results are described in Table 2.

${ }^{32}$ General John Wickham, White Paper 1984: Light Infantry Divisions (Washington, DC: Chief of Staff of the Army, 1984). The other three light infantry divisions were the $7^{\text {th }}$ Infantry at Fort Ord, CA, $25^{\text {th }}$ Infantry at Schofield Barracks, HI, and the $6^{\text {th }}$ Infantry at Fort Richardson, Alaska. The US Army was focused on organizing a highly deployable force that would be able to be available for contingencies in the world that lacked a developed support infrastructure. The successful rapid deployment of light infantry divisions during the US invasion of Panama in 1989 reinforced the concept of having a force ready to quickly deploy to a contingency.
} 
as a specialized force capable of mountain operations. Consequently, the US Army as of 2014

does not have active duty units trained in mountain warfare, because it is organized and equipped as general purpose units in accordance with US Army mountain warfare organizational doctrine as described in Field Manual 3-97.6 Mountain Operations (2000) and Field Manual 3-90.6 Brigade Combat Team (2010). ${ }^{33}$ The only mountain warfare instruction the US Army currently conducts is at the US Army Mountain Warfare School (AMWS) at Jericho, Vermont, Northern Warfare Training Center (NWTC) at Black Rapids, Alaska, and the mountain phase of Ranger School at Dahlonega, Georgia. However, each school focuses more on individual military mountaineering, rather than on training units and its leaders how to conduct mountain warfare. ${ }^{34}$

\section{MOUNTAINS AND WHERE THEY ARE}

It is essential to understand what a mountain is and where mountains are located in the world in order to recognize the likelihood of combat occurring in mountainous terrain. The term mountain refers to any land form that rises more than 1,625 feet (approximately 500 meters) above the surrounding plain and are often characterized by steep slopes. Mountains may consist of an isolated peak, single ridge, glaciers, snowfields, or complex ranges extending for long distances and obstructing movement. ${ }^{35}$

${ }^{33}$ Department of the Army, Field Manual 3-90.6, Brigade Combat Team (Washington, DC: HQ Department of the Army, 2010), 1-6 to 1-16. The US Army's basic structure as of 2014 is organized into three types of ground combat Brigade Combat Teams; Heavy, Stryker, and Light, where none routinely train for or are equipped for mountain warfare.

${ }^{34}$ This conclusion was attained by comparing the US Army Mountain Warfare School and Northern Warfare Training Center's student handout as well as from personal experience of the author. Each school publishes their own student course handout used for reference for their respective basic mountaineering courses. Additionally, Chapter 9 of the Ranger handbook contains a reduced twenty-seven page section on mountaineering techniques. The AMWS and NWTC handouts cover similar aspects of mountain warfare, but do not emphasize similar topics based on their geographical locations. Although both handouts are based in Field Manuals 3-97.6 and 3-97.61, the NWTC handout has more emphasis on cold weather operations and glacial mountaineering, while the AMWS handout emphasizes mountaineering and how to perform special techniques in mountainous terrain.

${ }^{35}$ Department of the Army, Field Manual 3-97.61, Military Mountaineering (Washington, DC: Department of the Army, 2002), 1-1. Slope can be characterized as a percentage. The percentage of slope indicates the amount of elevation increase for every 100 units of distance traveled. Complex mountain ranges are mountains that are formed from folds uplifted in the earth's crust due to tectonic movement, that are characterized by multiple mountains with multiple ridges congregated together. This is in contrast to a 
According to the US Army Mountain Warfare School, mountainous terrain consists of three operational levels that are associated with the altitude relative to mountainous terrain. The first level is located at the bottom of valleys and along the main lines of communications. This is where the majority of the local population is located and where heavy forces can operate, although maneuver space is often restricted. ${ }^{36}$ The second level is between valleys and shoulders of mountains, where narrow roads and trails serve as secondary lines of communication along ridge systems and motorized ground operations are difficult. The third level includes the dominant terrain of summit regions and can only be accessed by light forces. Although summit regions may contain relatively gentle terrain, mobility is difficult to achieve and maintain. ${ }^{37}$

Each operational level of terrain is unique and influences mountain warfare differently. Yet each can influence the operational levels that are below that level's respective elevation. The first level is considered key terrain in counterinsurgencies, such as what the US Army has experienced in Afghanistan, because this is where the population is. As you increase altitude and move into the second operational level, units trained in mountain warfare have a significant advantage over untrained units in conventional warfare. In the third operational level, units trained in mountain warfare have a significant advantage as they can utilize terrain thought to be unusable and attack the enemy from the flanks and rear. ${ }^{38}$

single mountain formed by a volcano like Mount Rainer in Washington State or dome structures pushed out of the earth's crust like the Black Hills in South Dakota. Field Manual 3-97.61 is the US Army's published doctrine on military mountaineering for individuals to reference for individual standards of how to operate in mountainous terrain. It was first published in 1976 as Training Circular (TC) 90-61 and renumbered in 2002 as Field Manual 3-97.61. It has been republished twice (1989 and 2002) since its first issue in 1976.

${ }^{36}$ Different types of units are referred to heavy and light. The term heavy refers to units that are mechanized or motorized. The term light refers to forces that maneuver on foot.

${ }^{37}$ US Army Mountain Warfare School, Military Mountaineer Course Student Handout (Jericho, VT: Army Mountain Warfare School, 2013), 61. The US Army Mountain Warfare School provides a handout to all students of the basic military mountaineering course, which combines Army doctrine of mountain operations, military mountaineering, and lessons learned during combat operations in mountainous terrain.

${ }^{38}$ US Army Mountain Warfare School, Military Mountaineer Course Student Handout (2013), 61. 
Over 35\% of the land mass in the world is mountainous terrain, where the principal mountain ranges of the world lie along the broad belts of mountains called cordillera. These mountain belts encircle the Pacific basin and lead westward across Eurasia into North Africa. Less rugged mountain chains lie along the margins of America and Europe. In North America a broad mountainous region about 1,000 miles (approximately 1,600 kilometers) wide dominates the northwestern part of the continent. It occupies much of Alaska, more than a quarter of Canada and all but a small portion of Mexico and Central America. In South America a continuous narrow band of mountains stretches along the western region. Narrower than its counterpart in the north at less than 500 miles (approximately 800 kilometers) wide, the South American mountain chain continuously exceeds an elevation of 10,000 feet (approximately 3,000 meters) for over 2,000 miles (approximately 3,200 kilometers). In Europe and northern Africa, the mountains are loosely linked systems separated by broad low basins and cut by numerous valleys. In Asia the mountainous terrain is more complex than in Europe as it reaches extreme

Figure 1. Mountain Regions of the World.

Source: Department of the Army, Field Manual 3-97.6: Mountain Operations (Washington DC: Department of the Army, 2000), 1-2. 


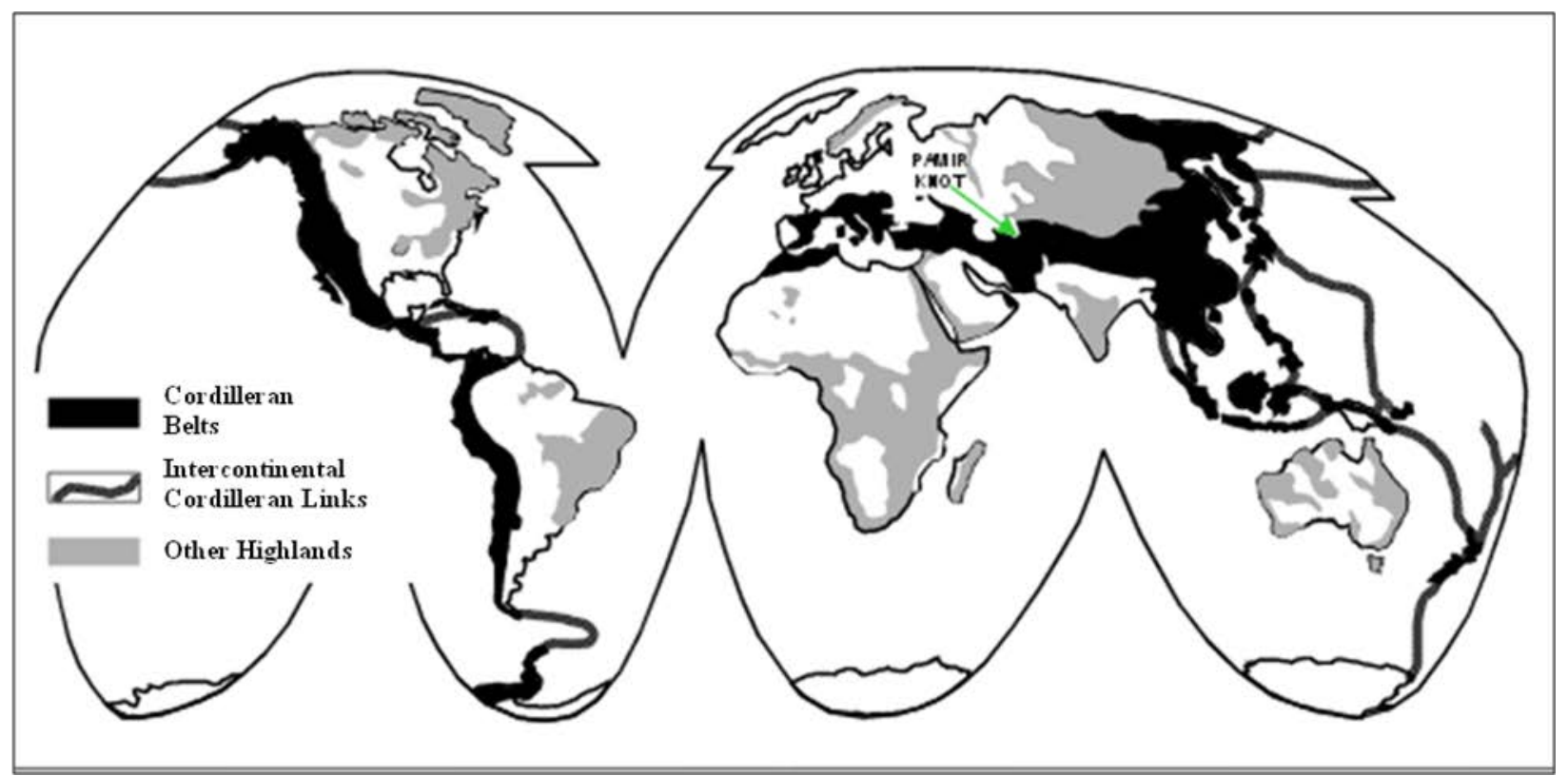

heights and contains the Himalayan mountain chain that has nine of the world's ten highest peaks.

The mountains in Asia fan out across eastern Asia with branches continuing south along the rugged island chains to New Zealand and north through the Bering Sea to Alaska (see Figure 1). ${ }^{39}$

Over $85 \%$ of countries with land borders have mountainous terrain. Mountainous borders are defined as land borders between two countries where within 50 miles (approximately 80 kilometers) of the border there is a difference in elevation of 1,625 feet (approximately 500 meters). ${ }^{40}$ Of the 193 countries that are members of the United Nations, 154 have land borders, and 132 of these countries have mountainous borders. Thirty-nine countries are island nations and

${ }^{39}$ Department of the Army, Field Manual 3-97.6, Mountain Operations (2000), 1-2 and 1-3: Lester Grau and Charles Bartles, Mountain Warfare and Other Lofty Problems: Foreign Perspectives On HighAltitude Combat (Fort Leavenworth, KS: Foreign Military Studies Office, 2011), 2. Grau and Bartles provide a comprehensive collection of translated foreign and English-language articles based on foreign sources that are about various aspects of mountain combat. It covers operations and tactics, artillery and aviation support, reconnaissance, communications, training, and logistics. The word cordillera is Spanish for rope. Figure 1 is from a US governmental source and is not copyrighted.

${ }^{40}$ Andrew Young, "Distance to the Horizon,” San Diego State Department of Astronomy, http://mintaka.sdsu.edu/GF/explain/atmos_refr/horizon.html (accessed January 12, 2014). The distance of eighty kilometers was determined by calculating what the maximum distance that could be seen from a point at sea level to a 500-meter mountain top taking into consideration the curvature of the earth and disregarding atmospheric conditions. The formula for this distance is: $d=3.57 \sqrt{\underline{E} \boldsymbol{h}}$, where $d$ is the distance in kilometers and ' $h$ ' is the height in meters of the observer. 
do not have land borders (See Table 3). ${ }^{41}$ Mountainous borders are important to the US Army because boundaries between countries are where geo-political interests intersect, insurgent forces are likely to go into hiding, and the invasion of countries begins.

\section{PECULIAR CHARACTERISTICS OF MOUNTAINOUS TERRAIN}

Mountainous terrain has peculiar characteristics that are critical to understanding mountain warfare, which are the effects of weather, effects on personnel, and effects on weapons and equipment. Mountainous terrain intensifies weather effects by effecting wind, temperature, and precipitation. Mountainous terrain affects soldiers by increasing caloric and water requirements, decreasing soldier performance, and causing severe injury. Mountainous terrain affects equipment and weapons by decreasing engine performance, altering weapon ballistics, and changing how weaponry functions. These peculiar characteristics can increase soldier loads, cause greater casualty rates, and increase unit logistical requirements. Unit leaders and their soldiers need a significant amount of time to train for and experience these peculiar characteristics in a mountainous environment because they are not found in non-mountainous environments and cannot be trained there. The peculiar characteristics are important for mountain warfare, because to not understand or plan for them can cause catastrophic operational effects by drastically affecting tactical operations.

\footnotetext{
${ }^{41}$ US National Geospatial Intelligence Agency, "Countries in the World with Mountainous Borders” (Analytical Research, St. Louis, MO, 20 January 2014): US Army Geospatial Center, “Country Borders with and Without Mountainous Borders” (Analytical Research, Fort Belvoir, VA, 25 February 2014): “United Nations Member States,” United Nations, http://www.un.org/en/members/index.shtml (accessed January 11, 2014). See Table 3 (Countries with and without mountainous borders) for which countries in the world have mountainous land borders. An analysis of all the national borders of countries in the world was conducted by the US National Geospatial Intelligence Agency using an unclassified digital elevation model called GTOPO 30, which has a 1 kilometer resolution for elevation data. Additional refinement for countries not identified by the GTOPO 30 analysis as mountainous was conducted by analyzing analog custom relief maps produced by the US Army Geospatial Center. The only countries analyzed were the 193 countries that are members of the United Nations.
} 
Mountainous terrain intensifies weather effects by affecting wind, temperature, and precipitation. The wind velocity increases with altitude and is intensified by mountainous terrain, because wind speed increases when winds are forced over ridges and peaks due to orographic lifting. Wind speeds increase in mountain valleys and canyons due to the Venturi effect. $^{42}$

The temperature in mountains on average decreases three to five degrees Fahrenheit on average per 1,000 feet (approximately 300 meters) elevation gain. The temperature decrease is compounded by increased winds, less cover from vegetation at higher elevations to block the wind and thinner air. The thinner air facilitates rapid cooling and heating from the sunlight, which can cause up to a $50^{\circ}$ Fahrenheit difference between temperatures in the sun and in the shade or after sunrise and sunset. ${ }^{43}$ Precipitation generally increases with altitude due to the rapid rise of air masses and can come in the form of rain or snow. In addition to the normal effects on military operations, precipitation in mountains creates the additional hazards of flash floods and avalanches. Heavy rains or fast thawing snow in combination with canalizing terrain causes flash floods, which not only are an obstacle to movement but can wash away a dismounted or mounted formation. Avalanches occur when the weight of accumulated snow on a slope exceeds the cohesive forces that hold the snow in place. ${ }^{44}$ Avalanches are a militarily significant planning factor in that they can cause casualties, damage equipment, block mobility corridors, and require the commitment of resources to clear. As evidence of the importance in planning military

\footnotetext{
${ }^{42}$ Department of the Army, Field Manual 3-97.6, Mountain Operations (2000), 1-7. Orographic lifting occurs when an air mass is forced from a low elevation to a higher elevation as it moves over rising terrain. The Venturi effect is a jet effect and is derived from the principles of fluid dynamics where a fluid (the air) velocity increases as it passes through a constriction. Wind speed and wind force is exponentially related, which means as the wind velocity doubles, the force on it quadruples.

${ }^{43}$ Department of the Army, Field Manual 3-97.6, Mountain Operations (2000), 1-4 to 1-6. The rate of temperature decrease can vary from wet to dry conditions. The temperature will decrease in humid conditions slower ( $1^{\circ}$ Fahrenheit every 330 feet, approximately 100 meters) or decrease faster in dryer conditions ( $\left(1^{\circ}\right.$ Fahrenheit every 165 feet, approximately 50 meters).
}

\footnotetext{
${ }^{44}$ US Army Mountain Warfare School, Military Mountaineer Course Student Handout (2013),
} 107. 
operations, avalanches caused an estimated 60,000 casualties along the Italian Front during the

First World War in the Alps. ${ }^{45}$ A summary of the comparison of weather effects between normal and mountainous environments can be seen in Table 4 (Comparison of Weather Effects).

Mountainous terrain affects soldiers by increasing caloric and water requirements, decreasing soldier performance, and causing severe injury. Soldiers operating in mountainous terrain require increased caloric intake due to the energy expended in maneuvering through uneven, potentially snow-laden, terrain in often cold conditions with large loads. Water requirements will increase in higher altitudes due to more rapid breathing as the human body tries to get more oxygen and increased evaporation of perspiration from dryer air. ${ }^{46}$

Mountainous terrain decreases soldiers' performance because it can cause loss of situational awareness, reduction of night vision capability, and inaccurate range estimates. Situational awareness can easily be lost in cold weather as soldiers will lose motivation to conduct military operations and only seek ways to stay warm through overdressing or staying inside of a warm shelter. This phenomenon is called cocooning and causes the soldier or unit (depending how many soldiers cocoon) to lose situational awareness around them and focus only on staying warm. Vision is the most noticeably affected sense at high altitudes. Night vision capability can be significantly reduced at altitudes over 8,000 feet (approximately 2,400 meters).

\footnotetext{
${ }^{45}$ Heinz Lichem, Gebirgskrieg 1915-1918: Ortler, Adamello, Gardasee (n.p.: Athesia, 1980); Heinz Lichem, Gebirgskrieg 1915-1918: Die Dolomiten Front (n.p.: Athesia, 1988); Heinz Lichem, Gebirgskrieg 1915-1918: Karnische Und Julische Alpen (n.p.: Athesia, 1989); Galli Richard, "Le Grande Guerra: The Italian Front 1915-1918,” Avalanche, http://www.worldwar1.com/itafront/avalan.htm (accessed February 15, 2014). These casualties mainly occurred over two winters 1915-1916 and 19161917. To put this amount of casualties into perspective, a total of 25,000 troops were killed by poison gas on the Western front during the First World War in Belgium and France. The amount of avalanche casualties is an estimate based on the research of Heinz Lichem and detailed in his three volume series of books describing the Italian Front during the First World War. Galli provides an excellent account of the effects of avalanches during the First World War on the Italian front.

${ }^{46}$ J.S.A Edwards, S.P.L Travis, and A.L. Dinmore, "Food and Nutritional Intake at High Altitudes”, Nutrition and Food Science 98, no. 1 (1998): 5-10. This article was a summary of a study, where its purpose was to measure and compare selected aspects of nutrition and food consumption both at sea level and at high altitude following acclimatization. It was determined that a higher altitude in itself or cold weather (outside of shivering if not properly clothed) does not increase the need for additional caloric intake. Increased caloric requirements were due to physical exertion related to moving across uneven sloped terrain burdened with equipment.
} 
The effects are not predictable on who it affects and when. Some soldiers are affected as they ascend to certain altitudes, while other soldier's night vision degradation may persist after acclimatization. Range estimation in mountainous terrain is difficult. Depending on the shape and type of the terrain, ranges will be over or underestimated. Soldiers who estimate range over smooth terrain such as sand, water, or snow will underestimate range. This will cause soldiers to engage targets beyond the maximum effective ranges of their weapon systems. Additionally, looking up or down a mountain has an effect. Looking downhill, targets appear to be farther away and uphill, they appear to be closer. This illusion, combined with the effects of gravity, causes downhill shots to fire high and the uphill shots to fire low. ${ }^{47}$

Mountainous terrain can cause severe injuries through either a deficiency in the amount of oxygen reaching tissue in the body or effects related to the mountain environment. When lack of oxygen fails to reach tissue in the body three types of altitude illnesses may occur: Acute Mountain Sickness (AMS), High Altitude Pulmonary Edema (HAPE), and High Altitude Cerebral Edema (HACE). There is no single determination if a soldier will get altitude sickness. It will depend on what the altitude is, the rate of ascent, the previous night's sleeping altitude prior to moving to the new altitude, and individual genetic physiological factors unique to each person. ${ }^{48}$ Additional effects of mountainous terrain include increased risk of cold weather injuries, carbon monoxide poisoning from the use of engines or combustion heaters in unventilated spaces, sleep disturbances from altitude induced sleep apnea, and poor wound healing from lower immune functions at higher elevations.

\footnotetext{
${ }^{47}$ Department of the Army, Field Manual 3-97.6, Mountain Operations (2000), 1-12 to 1-15.

${ }^{48}$ William Prayner, “Altitude Illness Prevention and Treatment” (Lecture, US Army Northern Warfare Training Center, Black Rapids, AK, July 12, 2012). This lecture was accompanied by a presentation at the US Army Mountain Warfare Orientation Course conducted by the Northern Warfare Training Center. Any of these altitude sicknesses can begin to manifest itself over altitudes of 8,000 feet (approximately 2,500 meters). The best treatment for Acute Mountain Sickness, High Altitude Pulmonary Edema (HAPE) and High Altitude Cerebral Edema (HACE), where HAPE and HACE are life threatening,
} is to reduce the soldier's elevation. 
Mountainous terrain affects equipment and weapons by decreasing engine performance, altering weapon ballistics, and changing how weaponry functions. Decreased engine performance is caused by lower atmospheric pressures which increase the evaporation of water in cooling systems and impairs the engine cylinders from breathing. As a result, engine power is reduced by 4 - 6\% and fuel and oil consumption increases up to 30\% more for every 3,300 feet (approximately 1,000 meters) of elevation increase. At 10,000 feet (approximately 3,000 meter) elevation, vehicles lose up to $25 \%$ of their carrying capacity and diesel engines may quit from lack of oxygen. ${ }^{49}$

The ballistics of a fired projectile is affected by the density of air, which is a function of the air pressure and temperature. Air density and temperature each affect the ballistics for different weapon types (rifles, artillery, and rockets) and munition sizes. Using a $7.62 \mathrm{~mm}$ rifle as an example, there is one minute of angle (MOA) increase for every 2,500 feet (approximately 770 meters) of elevation change or a decrease of one MOA for every temperature decrease of $20^{\circ}$ Fahrenheit. This would mean that a $7.62 \mathrm{~mm}$ rifle calibrated for firing at a 500 meter target at sea level at $70^{\circ}$ Fahrenheit would fire 12 inches (approximately $30 \mathrm{~cm}$ ) high at 10,000 feet (approximately 3,000 meters) of elevation minus other atmospheric conditions. ${ }^{50}$ Elevation and temperature changes may offset ballistic effects and soldiers may not see the immediate effects with small elevation changes and temperature differences. Yet these must be a consideration when moving between elevation and temperature extremes found in mountainous terrain to ensure that weapons are calibrated to aim correctly.

\footnotetext{
${ }^{49}$ Department of the Army, Field Manual 3-97.6, Mountain Operations (2000), 4-4; Grau and Bartles, Mountain Warfare and Other Lofty Problems: Foreign Perspectives On High-Altitude Combat, 3.

${ }^{50}$ US Army Mountain Warfare School, Military Mountaineer Course Student Handout (2013), 122. A minute of angle (MOA) is a measurement of an angle used in setting gun sights. A full circle is divided into 360 degrees and each degree is divided into 60 minutes. Thus, there are 21,600 minutes in a full circle $(360 \times 60=21,600)$. A rule of thumb is that changing a sight's elevation setting by one minute of angle changes the bullet's impact point three centimeters for each 100 meters of distance / or one inch for every 100 yards of distance. This calculation was determined to be a forty degree decrease in temperature resulting in a two minute decrease, but offset with a four minute increase due to altitude. Thus, the soldier would experience a two MOA increase and at 500 meters this results in a shot $30 \mathrm{~cm}$ higher than if fired at sea level.
} 
In addition to the effects of higher altitudes, the snow and cold temperatures found in mountainous terrain also affects how weaponry functions. Snow will increase dud rates of artillery and mortar rounds as well as absorb the explosion. In wet snow conditions, wire guided missiles may be ineffective because the wet snow will short out the wire connection between the gunner and the missile. When temperatures fall below freezing the back-blast from anti-tank weapons can be up to triple the distance and gunners have to avoid breathing on optical sights in order to prevent fogging. Visibility will be decreased by firing weapons at temperatures below $20^{\circ}$ Fahrenheit because it causes ice fog. Ice fog is created by the round as it leaves a weapon causing the water vapor in the air to crystallize, creating small ice particles. If this happens in a low wind environment, the ice fog can remain in the gunner’s line of sight for several minutes causing him to fire slower or force him to relocate to another position in order to maintain accurate fire. $^{51}$

\section{OPERATIONAL EFFECTS OF MILITARY OPERATIONS IN MOUNTAINOUS TERRAIN}

Basic tactics in mountainous terrain are the same as in other types of terrain. However, the application varies greatly with the terrain. ${ }^{52}$ Mountainous terrain affects operations differently than other terrain because it limits operational reach, restricts lines of operation, and complicates mission command. Operational reach is limited in mountainous terrain because military units are restricted to where and how fast they can travel, require more logistics, and have difficulties maintaining communications. Mountainous terrain restricts lines of operation due to

\footnotetext{
${ }^{51}$ US Army Mountain Warfare School, Military Mountaineer Course Student Handout (2013),
} 120.

${ }^{52}$ Department of the Army, Field Manual 1-02, Operational Terms and Graphics (Washington, DC: HQ Department of the Army, 2004), 1-183. Tactics is defined as the employment of units in combat to include the ordered arrangement and maneuver of units in relation to each other, the terrain, and the enemy in order to translate potential combat power into victorious battles and engagements. Field Manual 1-02 provides official definitions and descriptions for operational terms and graphics used in the US Army. 
predictability of key terrain, inadequate road networks, and vulnerable lines of communication. ${ }^{53}$ Mission command is more complex in mountainous terrain because it requires centralized planning, decentralized operations, and increased proficiency in junior leadership. Leaders and operational planners need to understand all of these factors why mountainous terrain affects operations in order to be successful. This is emphasized by Lieutenant Colonel Marcus Powell, a former instructor at the US Army Command and General Staff College who wrote in 1953 in regards to lessons learned during the Korean War, "If we do not understand these reasons, ....in each new campaign involving operations in mountainous regions, we have had to learn anew how to apply these principles. These lessons have usually come only after much bitter fighting with heavy losses in personnel, equipment, and prestige.”54

Operational reach is limited in mountainous terrain because military units are restricted to where and how fast they can travel, require more logistics, and have difficulties maintaining communications. Mountainous terrain restricts a military units’ capacity to maneuver dismounted or mounted due to slope, rough terrain and altitude. Mounted and mechanized vehicles cannot climb steep slopes or cross rough terrain, lose carrying capacity and consume more fuel. A dismounted unit's maneuverability is restricted by slope and rough terrain, which may require specialized equipment, specially trained climbers, and reduced travel time. A soldier's rate of dismounted movement in mountainous terrain slows with the increase of altitude and slope so much so that routes in mountainous terrain are measured in time not distance. The planning factor for dismounted units on level terrain is two and a half miles per hour (approximately four

${ }^{53}$ Department of the Army, Field Manual 1-02, Operational Terms and Graphics, 1-113. Line of communication is as a route, either land, water, and/or air, that connects an operating military force with a base of operations and along which supplies and military forces move.

${ }^{54}$ Marcus Powell, "Mountain Operations", Military Review (Jan 1953): 6-15. Lieutenant Colonel Powell wrote this article during the later part of the Korean War and was influenced by the struggles the US Army had in mountain operations on the Korean peninsula. His article is a good resource which provides a good foundation of the principles of mountain warfare, how these principles are applied in mountainous terrain, and a comparison of the application of these tactical principles in mountainous terrain versus less difficult terrain. 
kilometers per hour); however an additional hour needs to be added for every 1,000 feet (approximately 300 meters) of elevation gain or 2,000 feet (approximately 600 meters) of elevation loss. Additionally, for every twenty pounds over a 50 pound soldier load another fifteen minutes per mile (ten minutes per kilometer) is added to travel time. ${ }^{55}$

Military units have more logistical requirements because the aforementioned peculiar characteristics drive higher consumption rates of basic necessities, petroleum products, and repair part requirements. Soldier food and water requirements increase due to increased physical activity and hyperventilation caused by thinner air. Munition requirements grow due to increased rounds it takes to kill a target due to range estimation difficulties, altered ballistics and modified trajectories. Petroleum products consumption increases as the elevation increases due to less oxygen in the air. Repair part requirements increase due to colder temperatures causing plastic and moving metal parts to break. Due to the need for more logistical resupply, more planning effort and resources have to be allocated to sustain units in mountainous terrain.

Units have difficulty maintaining radio communications in mountainous terrain because of the challenges of rugged and steep terrain. Communications can be line-of-sight, satellite, landline, messenger or signal based. Communications that are line-of-sight based are the most commonly used, but their signals are absorbed by terrain folds and features of mountainous terrain. They are effective only for same side of mountain operations and still may have difficulties depending on the elevation and dead space between communication systems. Satellite-based communications are generally the most effective, but can still have problems based on the prevailing satellite angles in relation to the communication system. Land-line and messenger based communication systems can be effective, yet take time to setup or to move across rugged terrain, that in many instances makes these types of communications unpractical.

${ }^{55}$ William Prayner, “Route Planning for Operations in Mountainous Terrain” (Lecture, US Army Northern Warfare Training Center, Black Rapids, AK, July 12, 2012). This lecture was accompanied by a presentation at the US Army Mountain Warfare Orientation Course conducted by the Northern Warfare Training Center. A soldier's load includes the weight of everything that a soldier wears and carries. 
Using signals, such as smoke, flags, mirrors, or hand movements can be effective simple signals, but need to be trained and engrained into unit standard operating procedures and can be susceptible to low visibility conditions. ${ }^{56}$ Military leaders operating in mountainous terrain must understand these challenges in order to have a viable communications plan to maintain mission command capability.

Mountainous terrain restricts lines of operation due to the predictability of key terrain, inadequate road networks, and vulnerable lines of communication. ${ }^{57}$ Mountainous terrain focuses maneuver units on two predictable key terrain features; the heights that dominate valleys and passes, and the intersection of multiple valleys which facilitate movement through mountains. ${ }^{58}$ Each of these terrain features are key because they can control or influence maneuver corridors and lines of communication. These terrain features can influence or control the surrounding terrain through observation and being able to target direct or indirect fires onto the surrounding terrain. These key terrain features become even more important as elevation increases because the ability to access this terrain decreases. With this decreased accessibility, units require more mountain warfare capability and must commit more planning time and resources to seize key terrain. The analysis of where the key terrain is located must be completed at each of the three operational levels as there are few unconditionally impassable areas in mountains that can be considered an obstacle. Military leaders need to recognize that what is an obstacle to one force, may be key terrain to an opposing force that is organized and trained for mountain warfare.

\footnotetext{
${ }^{56}$ US Army Mountain Warfare School, Military Mountaineer Course Student Handout (2013), 176-177.

${ }^{57}$ Department of the Army, Army Doctrine Reference Publication 3-0, Unified Land Operations (2012), 4-4 to 4-5. Lines of operation is defined as a line that defines the directional orientation of a force in time and space in relation to the enemy and that links the force with its base of operations and objectives.

${ }^{58}$ Department of the Army, Field Manual 1-02, Operational Terms and Graphics (2004), 1-108. Key terrain is defined by the US Army as any locality, or area, the seizure or retention of which affords a marked advantage to either combatant.
} 
Mountainous terrain typically has inadequate road networks due to rugged terrain and decreased need for roads due to small local population bases. These inadequate road networks limit lines of operation by restricting access to mountainous terrain causing these areas to act like an obstacle, similar to a river. Mountains only allow certain points of access, splitting an attacker's avenue of advance, and confining the attacker to certain roads. This in turn allows the defender to mass their firepower on segments of the attacker's force. Additionally, a defender who has been defeated can often use the terrain in mountains to gain refuge and can choose advantageous terrain to defend with few options for an axis of attack against them. ${ }^{59}$

Lines of communication are vulnerable in mountainous terrain because of the combination of effects of rugged terrain, extreme weather conditions, and single road access points. Ground movement can be easily ambushed and have limited or no capability to bypass obstacles on the route. Helicopters are the preferred method of resupply, but carrying capacity reduces with increased elevation and temperature. Additionally, the US Army requires helicopters to be equipped with specialized equipment to provide oxygen to crew and occupants for flights over an hour duration at 10,000 feet (approximately 3,000 meters) of elevation or for any amount of time over 14,000 feet (approximately 4,300 meters). ${ }^{60}$ Space along routes for resupply points, landing zones for helicopters, or turn-around points for vehicles is limited or non-existent, which makes maintaining lines of communication tenuous at best. Military leaders need to take into account these factors combined with the obstacle-producing effects of mountainous terrain when planning

\footnotetext{
${ }^{59}$ Clausewitz, On War, 426.

${ }^{60}$ Department of the Army, Army Regulation 95-1, Aviation Flight Regulations (Washington, DC: HQ Department of the Army, 2008), 43-44; Department of the Army, Technical Manual 1-1520-240-10, Technical Manual Operator's Manual for Army CH47-D Helicopter (Washington, DC: HQ Department of the Army, 2003), 293-294. The CH47-D is a cargo helicopter and is used primarily in transporting troops and supplies for the US Army on the battlefield. The Technical Manual Operator's Manual for Army CH47-D provides planning criteria to calculate how much weight the CH47-D helicopter can carry at certain altitudes and temperatures. With a helicopter laden with the maximum 33 combat loaded troops a CH47-D helicopter will weigh approximately 35,000 lbs, which according to Technical Manual 10-1520240-10 can to fly up to 16,000 feet (approximately 4,900 meters) at $0^{\circ} \mathrm{F}$ or 11,500 feet (approximately 3,500 meters) at $90^{\circ} \mathrm{F}$. This is only a calculation on how high the helicopter can fly and does not take into account the decrease of flying time available due to increased fuel usage.
} 
operations to be able to have viable lines of communication to support their forces in mountainous terrain.

Mission command is more complex in mountainous terrain because it requires centralized planning, decentralized operations, and a higher level of junior leadership abilities. Mountainous terrain requires centralized planning because the scheme of maneuver of a force as a whole is based on detailed planning to ensure unity of effort and adequate and continuous support. ${ }^{61}$ This unity of effort and continuous support is difficult to coordinate as engagements tend to be isolated, ground columns are narrow and stretched out, and mutual support positions are difficult to establish. Senior military leaders have a difficult time repositioning in mountainous terrain and need to ensure that they have a cohesive well thought out plan to minimize friction since situational awareness will be diminished. ${ }^{62}$

Decentralized operations are used in mountainous terrain because the terrain is compartmentalized and there is limited maneuver space. The compartmentalized terrain does not allow units to mutually support each other causing forces to operate semi-independently in order to capture terrain objectives. Mountainous terrain restricts the size and types of military forces that can be used due steep valleys and defiles. Consequently, units that conduct mountain warfare have to maneuver independent of other elements, and are decentralized. ${ }^{63}$

Mountain warfare demands a higher level of leadership abilities in junior leaders because junior level leadership is decisive in and out of combat on mountainous terrain. Junior leaders at the platoon and squad level in combat are critical to success due to the decentralized and smallunit nature of mountain warfare in compartmentalized rugged terrain. The Russians in Afghanistan observed that the quality of junior leadership is decisive, as even a small unit, maneuvering boldly, could decide the outcome of a battle by using disciplined initiative,

\footnotetext{
${ }^{61}$ Powell, "Mountain Operations", 6.

${ }^{62}$ Department of the Army, Field Manual 3-97.6, Mountain Operations (2000), 2-2.

${ }^{63}$ Powell, "Mountain Operations", 6.
} 
unexpectedly maneuvering around a defender's flank or capturing a dominating height. ${ }^{64}$ Junior leaders’ ability to recognize and address physical and psychological fatigue is critical in mountainous terrain at high elevations and colder weather, to quickly identify signs of deterioration before they become pronounced or a catastrophic event occurs. ${ }^{65}$ There are three major leadership challenges in mountainous terrain (in addition to normal small-unit leadership challenges) that leaders have to contend with in regards to their soldiers: cocooning, group hibernation, and loss of personal contact and communication. Cocooning as previously described can cause loss of situational awareness. Group hibernation is where a unit collectively cocoons, there is a complete failure of small unit leadership and group discipline in maintaining situational awareness and unit security is lost. Loss of personal contact and communication for soldiers can result due to the isolated nature and limited communication ability in mountainous terrain. As a result, soldiers feel depressed and apathetic, while units lose cohesion and esprit de corps. ${ }^{66}$

\section{TRAINED AND UNTRAINED UNITS IN MOUNTAIN WARFARE}

Military units trained in mountain warfare are more successful than untrained military units because they have the specialized technical skills and equipment to operate in an austere mountainous environment, their leaders understand how to plan for the operational effects of mountainous terrain, and mountain units have better cohesion and esprit de corps from arduous specialized training. Below are two case studies to illustrate how being mountain warfare trained is a contributor to units' combat success in mountainous terrain. The first case study is of the US Army's $10^{\text {th }}$ Mountain Division during the Second World War in northern Italy during Operation ENCORE. The second case study is of the Indian $4^{\text {th }}$ Infantry Division's unsuccessful mountain

${ }^{64}$ Sray, John, “Mountain Warfare: The Russian Perspective,” US Army Foreign Military Studies Office. (Fort Leavenworth, March 1994). Web. http://fmso.leavenworth.army.mil/documents/mountain.htm (accessed January 22, 2014).

${ }^{65}$ Muhammad Malik, "Mountain Warfare: The Need for Specialist Training" (Master Thesis, Command and General Staff College, Fort Leavenworth, KS, 2003), 22-23.

${ }^{66}$ William Prayner, "Mountain Leadership” (Lecture, US Army Northern Warfare Training Center, Black Rapids, AK, July 12, 2012). 
operations in 1962 against the Chinese People’s Liberation Army (PLA) in the Kameng Frontier of the Indian North East Frontier Agency (N.E.F.A.) near Tibet. Each of these case studies illustrates the importance of how mountain warfare (or lack thereof) contributes to the operational success or failure of a military infantry division in mountainous terrain.

\section{Case Study \#1: Mountain Warfare Success - Operation ENCORE}

Nearly a year before the $10^{\text {th }}$ Mountain Division arrived in the Mediterranean theater of war in Italy, Allied leaders (United States President Franklin Roosevelt, Great Britain Prime Minister Winston Churchill, and free French forces Generals Charles de Gaulle and Henri Giraud) met in January 1943 at the Casablanca conference in Morocco to decide on how to execute the next phase of the Second World War. At that conference, Roosevelt and Churchill decided to invade Sicily after the ongoing northern African operations were successfully completed in order to accomplish three objectives; secure Allied lines of communication in the Mediterranean, divert German strength from the Soviet Union during the summer of 1943, and force Italy out of the war. An Italian surrender was critical to the Allies as it meant that the Germans would lose the use of twenty-nine Italian divisions in the Balkans and five in France and they would no longer be available for occupation duties and coastal defense. ${ }^{67}$

On 3 September 1943, Italy surrendered as the Allied Force Commander General Dwight Eisenhower decided to continue their offensive beyond Sicily into the Italian peninsula due to the Allies’ overwhelming success in Sicily. In the meantime, the Germans had evacuated the majority of their troops successfully from Sicily and moved in additional units to defend northern Italy. The Germans wanted to defend northern Italy in order to maintain access to the food resources and munition factories in the Po River Valley and deny the Allies access to northern Italian airfields for bombing Germany from the south. Consequently, the Germans developed the

${ }^{67}$ Martin Blumenson, The Mediterranean Theater of Operations: Salerno to Cassino (Washington, DC: Center of Military History, 1969), 1-26. This is the US Army official history of the first part of the Italian operations during the Second World War and provides a very well written narrative of the strategic context and history from the Allied invasion of mainland Italy from September 1943 through March 1944. 
strategy of defending critical mountain passes in the Apennine Mountains in a series of fortified defensive zones from south to north along the Italian peninsula beginning directly south of Rome. ${ }^{68}$ By December 1944 the Allies had liberated Rome and became bogged down in and around the German fortified defensive zone called the Gothic line. Offensive operations had culminated in the Apennine Mountains south of the Po River valley due lack of ammunition and replacements for casualties. ${ }^{69}$

$10^{\text {th }}$ Mountain Division was organized in July 1943 at Camp Hale, Colorado and new soldiers assigned to the $10^{\text {th }}$ Mountain Division were selected by the National Ski Patrol System. ${ }^{70}$ The Mountain Training Center (formed two years earlier) located at Camp Carson, Colorado, facilitated the technical aspects of the training and the center's cadre eventually were assigned to the $10^{\text {th }}$ Mountain Division to provide a core group of experienced leadership. The $10^{\text {th }}$ Mountain Division continued to train, organize, and determine the equipment they would need for operations in an austere mountainous environment. Their mountain training culminated in a series of exercises between 26 March and 15 April 1944 in temperatures between $-25^{\circ} \mathrm{F}$ to $39^{\circ} \mathrm{F}$, at altitudes above 12,000 feet (approximately 3,700 meters), and average snow depths over six feet (approximately two meters). Even after a successful division level mountain exercise,

\footnotetext{
${ }^{68}$ Peter Shelton, Climb to Conquer: The Untold Story of World War II's 10th Mountain Division Ski Troops (New York: Scribner, 2003), 119. This book describes a narrative history of the $10^{\text {th }}$ Mountain Division during the Second World War.

${ }^{69}$ Fisher, US Army in WWII Mediterranean Theater of Operations: Cassino to the Alps, 297-301. The Gothic line was a 180 mile long, twenty mile (approximately 300 x 30 kilometer) wide defensive zone. Within this defensive zone the civilian population was evacuated, all roads and bridges were destroyed or rigged for demolition, and complex obstacles (anti-tank ditches, mines, and wire entanglements) were emplaced on key terrain to disrupt and prevent movement. The Germans also depended on a mobile reserve of self-propelled anti-tank guns to reinforce critical choke points, which were vulnerable to Allied air power.

${ }^{70}$ Shelton, Climb to Conquer: The Untold Story of World War II's 10th Mountain Division Ski Troops, 6-47. This was the first time in US Army history that a civilian organization was allowed to select troops. In order to be selected for the $10^{\text {th }}$ Mountain Division, new enlistees/ draftees had to submit three letters of recommendation, attesting to skiing and/or outdoor experience. In contrast to normal Army units, new enlistees / draftees had to only pass a physical. The President of the National Ski Patrol, Minnie Dole, spearheaded the word of mouth campaign as he said, "It is easier to train a skier to be a soldier than to train a soldier to be a skier.”
} 
Army leaders were skeptical on how the $10^{\text {th }}$ Mountain Division would be employed.

Consequently, the $10^{\text {th }}$ Mountain Division was sent to Camp Swift, Texas in June 1944 to

acclimate to hot weather and train the organization on heavier weapons and motorized equipment

in order to be able to fight along other regular infantry divisions. Although this was unpopular

with leaders and soldiers within the $10^{\text {th }}$ Mountain Division they were able to train with heavy

machine guns, air cover, and learn how to operate in extreme heat. In November 1944, the $10^{\text {th }}$

Mountain Division received orders to deploy to the Mediterranean theater of operations in Italy to be assigned to Fifth Army. They arrived in Naples, Italy in the beginning of January $1945 .{ }^{71}$

General Mark Clark, $15^{\text {th }}$ Army Group Commander, planned to conduct a spring offensive

to break out of the Apennine Mountains into the Po River Valley. From the Allied controlled city

of Florence there were only two main routes through the mountains north to the industrial and rail center of Bologna; Highway 64 and 65 (See Figure 2). ${ }^{72}$ Highway 65 was heavily defended by the Germans and Highway 64 was over watched by the mountain Monte Belvedere. Monte Belvedere was a 3,800 foot (approximately 1,200 meter) high mountain, with a patchwork of woods and farmland, where German observers could direct artillery fire onto any movement approaching Highway 64. Fifth Army realized that in order to take Monte Belvedere, they would need to take the rugged escarpment code-named Riva Ridge, because from Riva Ridge any movement against Monte Belvedere could be observed and targeted. Lieutenant General Lucian Truscott, commander of Fifth Army, decided that the main effort should attack along Highway 64. Fifth Army attempted to seize this ground twice in December 1944 with the Brazilian

\footnotetext{
${ }^{71}$ Govan, Training for Mountain and Winter Warfare: Study Number 23, 12-14; Shelton, Climb to Conquer: The Untold Story of World War II's 10th Mountain Division Ski Troops, 110-116. The Allied Headquarters on the Italian peninsula was $15^{\text {th }}$ Army Group and was led by British General Harold Alexander until December 1944, when US Fifth Army commander General Mark Clark assumed command. $15^{\text {th }}$ Army Group had two armies assigned to it; the US Fifth Army commanded by Major General Lucian Truscott and the British Eighth Army commanded by Lieutenant-General Richard McCreery. The US Fifth Army was responsible for the western side of the Italian peninsula and the British Eighth Army the eastern side.

${ }^{72}$ Figure 2 has been adapted and modified by the author from its original source and has been determined by the Fort Leavenworth Copyright coordinator, Susan Fowler, not to infringe on copyrights.
} 
Expeditionary Force (BEF), but failed. ${ }^{73}$ A plan for a new offensive was developed and was named Operation ENCORE. The $10^{\text {th }}$ Mountain Division was chosen to be the main effort due to their mountain capability and the likelihood the Germans would discount the US Army’s ability to attack through severely restricted mountainous terrain. ${ }^{74}$

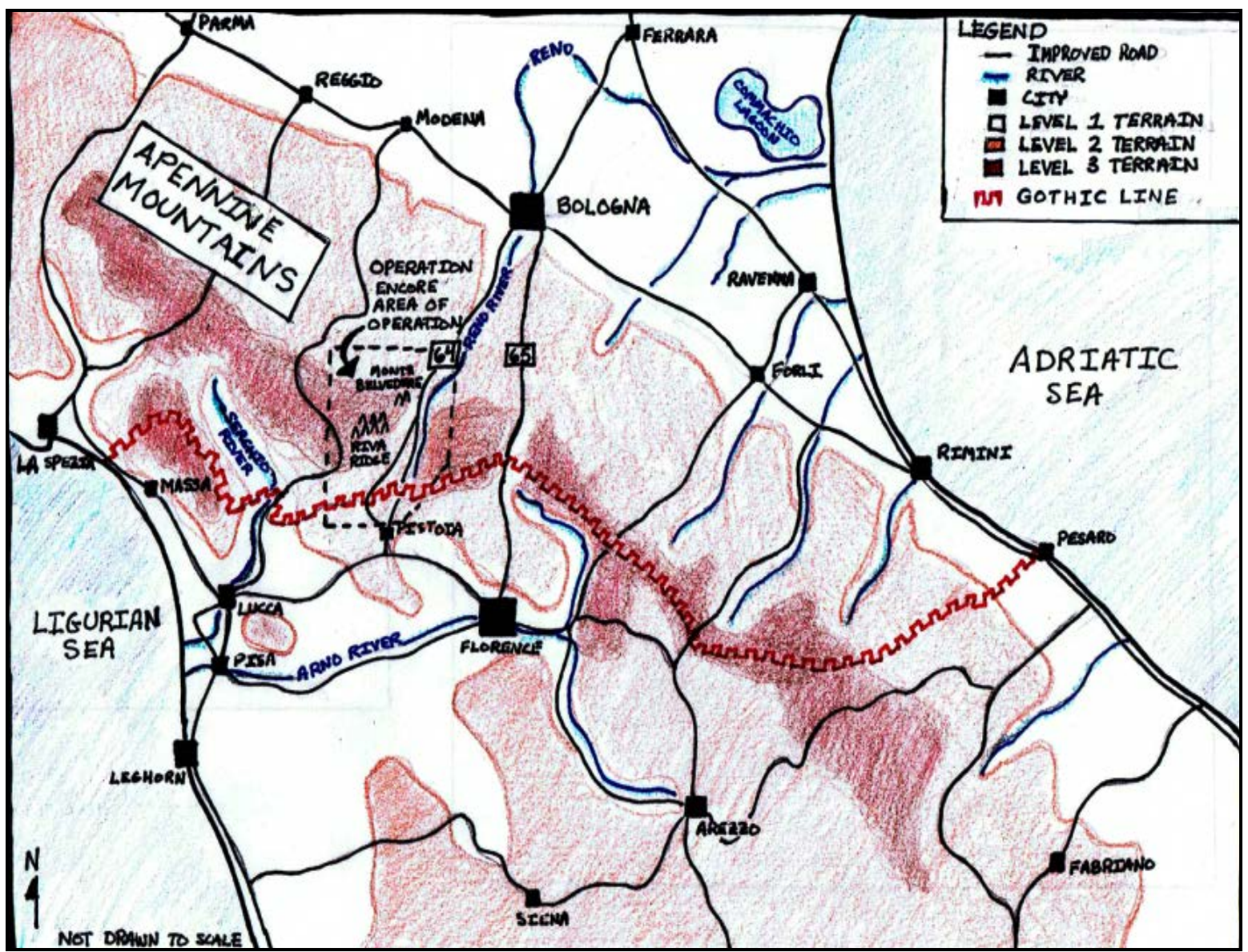

Figure 2. Map of Central Italy and Area of Operations for Operation ENCORE.

Source: Adapted from Thomas R. Brooks, The War North of Rome, June 1944-May 1945 (New ('York: Sarpedon, 1996), 418-419.

excellent account of the origins of the Brazilian Expeditionary Force and its operations in the Italian peninsula during the Second World War.

${ }^{74}$ Thomas R. Brooks, The War North of Rome, June 1944-May 1945 (New York: Sarpedon, 1996), 350; Henry Hampton, The Riva Ridge Operation: Report On the Mancinello-Campiano Ridge Operation of the 1st Battalion, 86th Mountain Infantry (Udine: Headquarters 86th Infantry Regiment, 1945); Shelton, Climb to Conquer: The Untold Story of World War II's 10th Mountain Division Ski Troops, 121. Riva Ridge is the code name given to the escarpment called the Mancinello-Campiano Ridge, which is a seven mile chain of mountain summits with steep slopes ranging from 3,100 - 6,000 feet (approximately 1,000 1,800 meters) consisting of the peaks Monte Pizzo di Campiano, Cappel Buso, Serrasiccia, Riva, Mancinello, and Le Piagge. Lieutenant Colonel Hampton's account of the Riva Ridge operation is from the perspective of a battalion commander. 
The purpose of Operation ENCORE was to secure Riva Ridge and Monte Belvedere dominating a ten-mile section of Highway 64 in order to prevent the Germans from being able to influence operations along the Highway 64 corridor. The $10^{\text {th }}$ Mountain Division's plan was to first secure Riva Ridge with a battalion task force of the $86^{\text {th }}$ Infantry Regiment. Next the $87^{\text {th }}$, $85^{\text {th }}$, and one battalion from the $86^{\text {th }}$ Infantry Regiment would secure Monte Belvedere and the ridgeline to Monte Torraccia. Finally, the Brazilian Expeditionary Force was assigned to be the eastern flank security of the $10^{\text {th }}$ Mountain Division (See Figure 3$)^{75}$.

For two weeks prior to Operation ENCORE the $1^{\text {st }}$ Battalion $86^{\text {th }}$ Infantry Regiment (1-86 MTN IN) task force assigned the mission of securing Riva Ridge conducted reconnaissance and located five different routes for the ascent to the summits of Riva Ridge, which required fixed ropes on different sections of two of the routes. ${ }^{76}$ The $10^{\text {th }}$ Mountain Division had intelligence that the Germans had 170 men located on Riva Ridge, with an estimated 40-50 men, manning well-dug-in positions covering avenues of approach. The commander of $10^{\text {th }}$ Mountain Division, Major General George Hays, decided that in order to have a successful attack his troops would ascend each of the ridgelines in preceding nights. Hays ordered his units not to use preparation artillery fire, and only use bayonets knives and grenades for weapons (no loaded rifles) in order to maintain the element of surprise against the Germans. ${ }^{77}$

${ }^{75}$ Figure 3 has been verified with the Fort Leavenworth Copyright coordinator, Susan Fowler, for use under the fair use exemption in regards to copyright.

${ }^{76}$ The 1-86 MTN IN task force consisted of four infantry companies (A,B,C 1-86 MTN IN) and F Co 2-86 MTN IN. A Company 1-86 MTN IN ascended Riva Ridge along two different pathways.

${ }^{77}$ Shelton, Climb to Conquer: The Untold Story of World War II's 10th Mountain Division Ski Troops, 144. General Hays order read, "No arms are to be used before daylight; the aim is to slip past the German positions if possible and gain the high ground behind them. Positions that cannot be bypassed are to be eliminated with bayonets, knives, and grenades. If we don't fire our weapons, the defenders will not know where we are or what our strength is. Artillery an air support will come only after daybreak and after initial objectives have been taken.” 
On 18-19 February 1943, 1-86 MTN IN taskforce conducted a successful assault of Riva Ridge. Assault climber teams began to scale the 1,500 foot (approximately 500 meter) face of Riva Ridge at 1930 hours after sunset and set in fixed rope systems for follow-on units to use for the ascent. Once the assault platoons reached the edge of the ridge line, they signaled for the main body to follow. At dawn, the entire battalion task force had reached the top undetected due to their unit's ability to scale terrain that the Germans thought untenable by American units. In the morning the Germans realized that the Americans were on the ridge line, but the American force was dug in and the German infantry counterattacks were repulsed. By the evening of 19 February, Riva Ridge was secured.

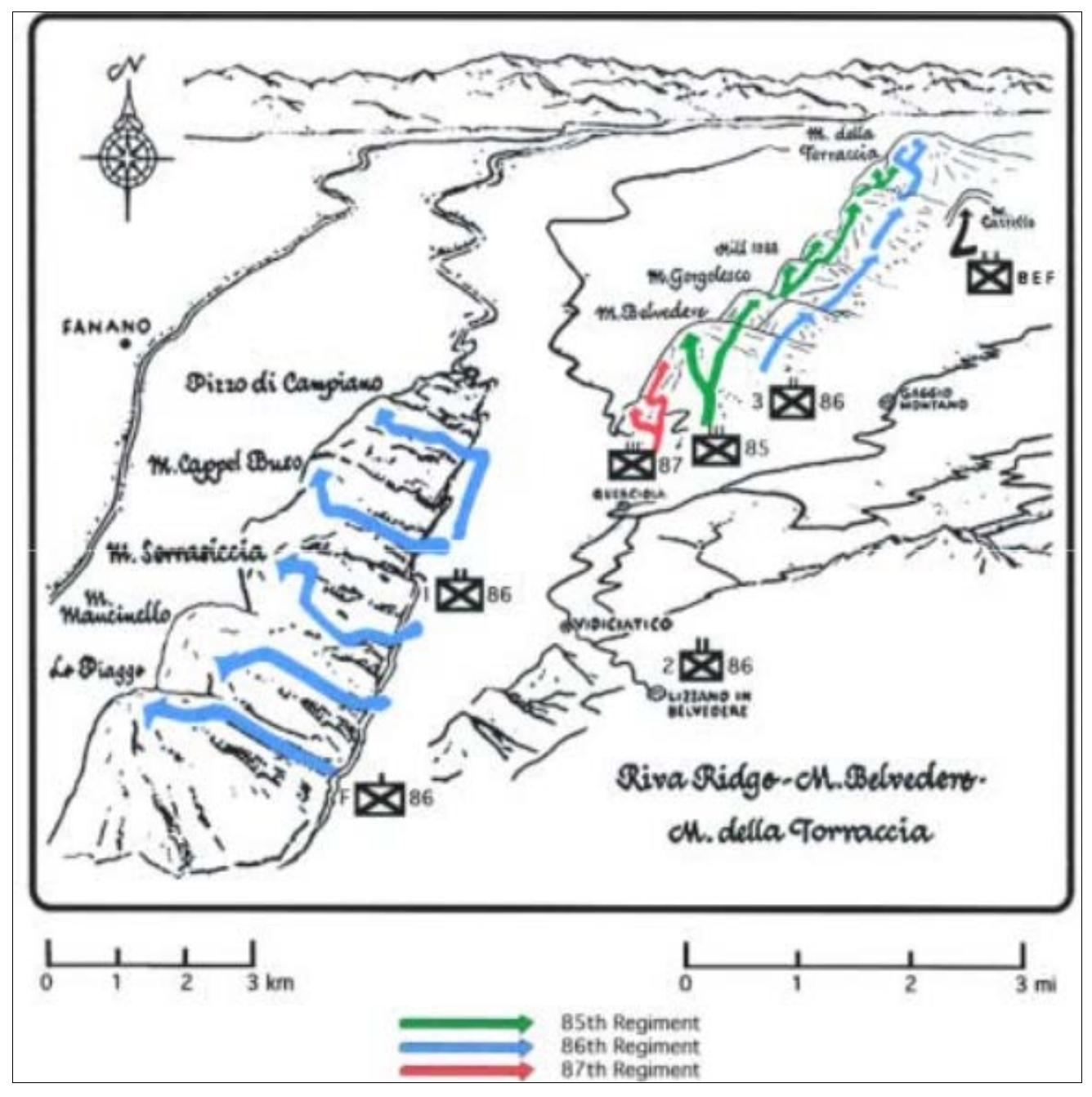

Figure 3. Operation ENCORE - Riva Ridge \& Monte Belvedere to Torraccia.

Source: John Imbrie, Chronology of the 10th Mountain Division in World War II: 6 January 1940 - 30 November 1945 (Lakewood: Błational Association of the 10th Mountain, 2004), 15. 
For resupply on Riva Ridge an engineer company attached to 1-86 MTN IN completed an aerial tramway near the peak of Monte Cappel Buso. On the first day of operation thirty wounded were evacuated and five tons of supplies were delivered to the summit from the valley floor. This was the first time in US military history this was done, which eliminated the need for porters or mules to travel pathways carrying supplies to troops in level three operational terrain. ${ }^{78}$

On 19 February 1943 at 2300 hours, the remainder of the infantry elements within the $10^{\text {th }}$ Mountain Division attacked Monte Belvedere and Monte Gorgolesco after an eight-mile foot march the previous night. The $1^{\text {st }}$ and $2^{\text {nd }}$ Battalions of the $87^{\text {th }}$ Mountain Infantry Regiment (187 MTN IN and 2-87 MTN IN respectively) attacked northeast along the western slope of Monte Belvedere. The $3^{\text {rd }}$ Battalion $85^{\text {th }}$ Mountain Infantry Regiment (3-85 MTN IN) attacked along the eastern slope toward Monte Gorgolesco. The Germans were again surprised as the first resistance on Monte Belvedere for 3-85 MTN IN began 1,000 feet (approximately 300 meters) short of the summit. The initial objectives on Monte Belvedere were secure by dawn of 20 February. The subsequent peaks were assaulted by the remaining battalions of the $85^{\text {th }}$ Regiment as they conducted passage of lines through each other in order to maintain the operational initiative. By the evening of 20 February, the attack on the final summit of Monte Torraccia commenced. The next day four battalions of the Brazilian Expeditionary Force captured Monte Castello to secure the $10^{\text {th }}$ Mountain Division's right flank. The Germans, after two days of fighting on the Belvedere-Torraccia massif, were able to mount numerous counterattacks and delay the $10^{\text {th }}$

${ }^{78}$ Fisher, US Army in WWII Mediterranean Theater of Operations: Cassino to the Alps, 430-433; John Imbrie, Chronology of the 10th Mountain Division in World War II: 6 January 1940 - 30 November 1945 (Lakewood: National Association of the 10th Mountain, 2004), 16-17. The assault platoons lead climbed in the darkness and set in fixed lines by driving in steel pitons into rocks with fabric covered mallets, hooked snap links to them, and then fastened ropes to the snap links to provide fixed hand lines for the main body of climbers to follow. 
Mountain Division from securing Monte Torraccia for three additional days. However, by 25

February the $10^{\text {th }}$ Mountain Division secured the Belvedere-Torraccia massif and set the conditions for Fifth Army in the spring of 1945 to break through the German Apennine Mountain defenses into Po River valley. ${ }^{79}$

There were many contributing factors to the success of $10^{\text {th }}$ Mountain Division in Operation ENCORE, but the most critical was that they were trained for mountain warfare. This conclusion was echoed by the $1^{\text {st }}$ Battalion, $86^{\text {th }}$ Infantry Regiment Commander Lieutenant Colonel Henry Hampton's after action report on his battalion's actions on Riva Ridge, when he attributed his battalion’s success with the following statement, “70\% of the personnel had been mountain trained in the American Rockies. They had no fear of rugged, precipitous and difficult terrain.”80 Due to $10^{\text {th }}$ Mountain Division's technical expertise and use of specialized equipment they were able to set in fixed rope systems, which allowed them to secure Riva Ridge and build an aerial tramway for casualty evacuation and resupply. Leaders demonstrated their ability to operate in mountainous terrain by understanding how to identify and seize decisive terrain in a mountainous environment. Unit cohesion and esprit de corps of the $10^{\text {th }}$ Mountain Division units was critical in maintaining noise discipline during their ascents as well as conducting a mountain assault with unloaded rifles to maintain the element of surprise. The $10^{\text {th }}$ Mountain Division demonstrated that they could succeed where other units had failed before.

Case Study \#2: Mountain Warfare Failure - Battle in the Kameng

In October 1962, the People’s Liberation Army (PLA) of China attacked the Indian outposts in India’s North-East Frontier Agency (N.E.F.A.) and Ladakh (a region of Kashmir in northern India) in order to take over strategic routes that would allow China to keep its line of

${ }^{79}$ Brooks, The War North of Rome, June 1944-May 1945, 353-358.

${ }^{80}$ Hampton, The Riva Ridge Operation: Report On the Mancinello-Campiano Ridge Operation of the 1st Battalion, 86th Mountain Infantry, 12. This was the first of eight reasons he attributed the success of his battalion too. 
communications to Lhasa, the capital of Tibet, and western Tibet open. ${ }^{81}$ The origins of the Chinese offensive against India began in 1950, when China acted on its expansionistic views and invaded the country of Tibet. With China's conquest of Tibet, the Chinese borders came in direct contact with India along the 2,500 mile (approximately 4,200 kilometer) mountainous Himalayan border. Until the Tibetan invasion, India had been a friendly ally to the People's Republic of China since declaring its independence in 1949. However, India began to become suspicious of China's intentions with the conquest of Tibet. Additionally, provocative literature from China's leader Chairman Mao Zedong, and a well publicized cartographic invasion of Indian territory (where Chinese maps showed over 48,000 square miles, approximately 125,000 square kilometers, of Indian territory within China) reinforced this belief. The majority of the areas in question were located in the Indian region of Ladakh and the Indian N.E.F.A.. (Figure 4) ${ }^{82}$

After the invasion of Tibet, India engaged China to negotiate on settling outstanding issues inherited with the Chinese occupation of Tibet and strengthen its friendship with China despite its recent aggression. As a result, China and India signed two different agreements. The first agreement was the Seventeen Points Agreement which was signed in May 1951. In the Seventeen Points Agreement, India recognized China’s historical sovereignty over Tibet, but still preserved India's economic and social interests in Tibet. The second agreement called the “Pansheel Agreement” was signed in 1954, which became widely known as the Five Principles of

\footnotetext{
${ }^{81}$ India’s North Eastern Frontier Agency is the name given to seven districts (Kameng, Subsansiri, Tirap, Siang, Lohiti, and Tuensang) of north-eastern India in 1954. The North-East Frontier Agency was formerly known as the North-East Frontier Tracts and was a political division of former British India.

${ }^{82}$ Dr. P. B. Sinha and Colonel A. A. Athale, History of the Conflict with China, 1962 (New Delhi: History Division Indian Government Ministry of Defence, 1992), 1-4. This border includes the country of Bhutan's border, since India by treaty is responsible for the defense of Bhutan, which in effect makes the Bhutan border India's border. This historical document was commissioned by the Indian government and is a comprehensive history from the Indian perspective of the China-Indian conflict in 1962. Figure 4 is from a US governmental source and is not copyrighted.
} 


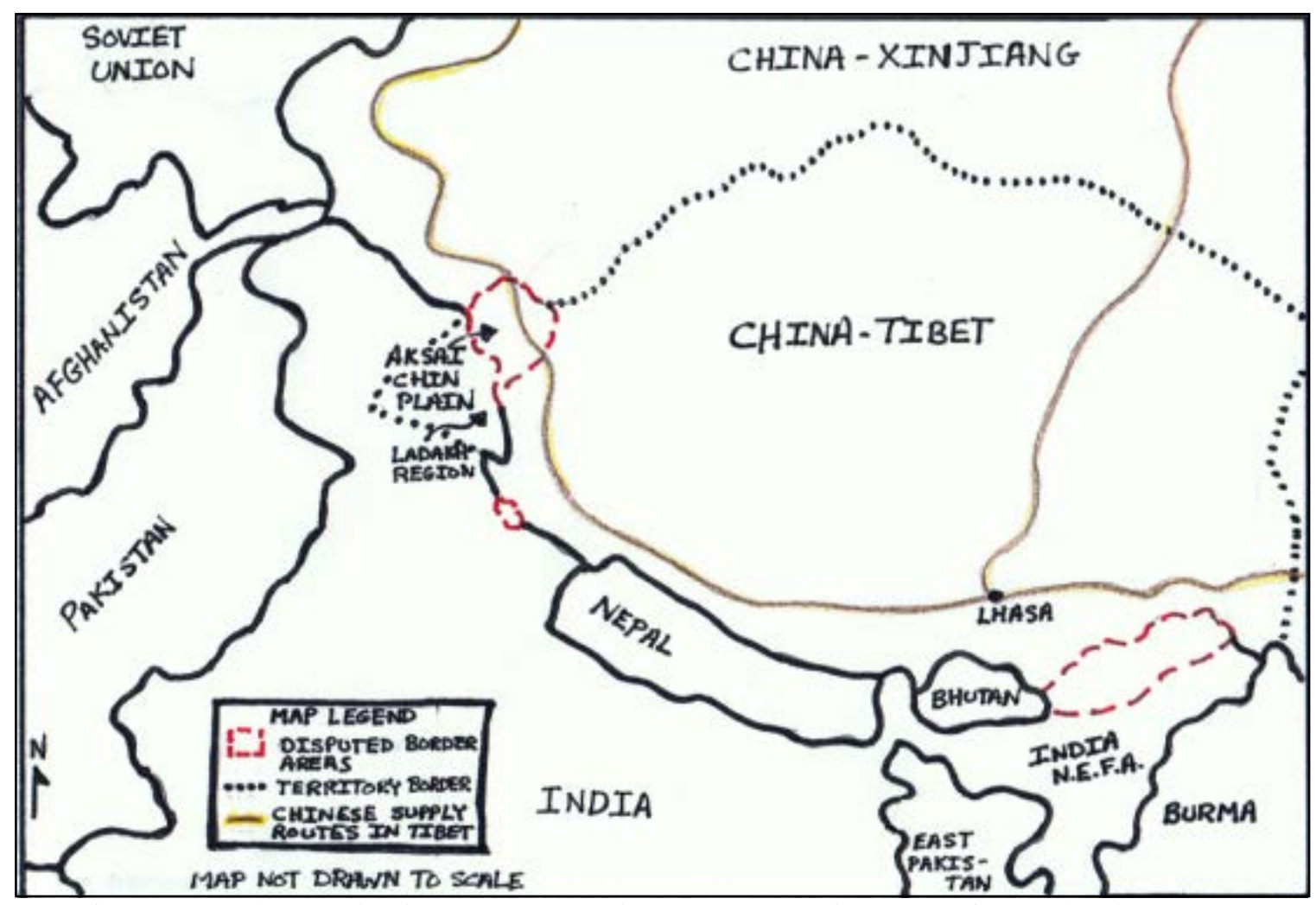

Co-existence. In the Pansheel Agreement each country agreed to recognize each other's

respective borders. ${ }^{83}$

Figure 4. Geographical Overview of 1962 Indian-China Frontier.

Source: Adapted from Arthur Cohen, The Sino-Indian Border Dispute: Section 3: 1961-1962 (Washington, DC: CIA, 1964), 80.

China began to assert its claims in parts of the Indian territory of Ladakh as well as areas in the N.E.F.A. within months after signing the Pansheel Agreement. China recognized during the Tibetan invasion the difficulties of maintaining a logistical supply chain across the rugged terrain of eastern Tibet to the western border areas and needed a route from the Chinese western

${ }^{83}$ Aldo Abitbol, “Causes of the 1962 Sino-Indian War: A Systems Level Approach”, Josef Korbel Journal of Advanced International Studies (March 2011): 74-87; Agreement Between the Republic of India and the People's Republic of China on Trade and Intercourse Between Tibet Region of China and India, April 24, 1954, UNTS 299, no. 4307, pt. 6 (1954), 57-81. The five principles of co-existence were mutual respect for each other's territorial integrity and sovereignty, mutual non-aggression, mutual noninterference in each other's internal affairs, equality and mutual benefit, and peaceful co-existence. 
province of Xinjiang to supply western Tibet. As early as 1951 China used a narrow wagon trail along an ancient route of the Silk Road to resupply western Tibet and Lhasa from the western Chinese province of Xinjiang. However, a portion of this route crossed the Indian territory of Ladakh in an area called the Aksai Chin Plain, which was an unpopulated high altitude flat salt plateau with an average elevation of over 16,000 feet (approximately 5,000 meters) above sea level. The Indian government did not maintain any administrative presence in this desolate area outside of an occasional reconnaissance patrol by frontier police. Consequently, China decided to improve this ancient route of the Silk Road to be able to handle cargo trucks, regardless of Indian sovereignty or the principles outlined in the Pansheel Agreement.

China completed this road in 1957 after two years of improving this route into a truck capable roadway, which linked western China to Tibet across 100 miles (approximately 160 kilometers) of India. China secured the route by pushing PLA outposts further into Indian territory, which effectively annexed the majority of the Aksai Chin Plain to China. The Indian government did not find out about the Chinese Xinjiang-Lhasa road until 1958 due to the isolation and difficulty in accessing this area. India protested to China, but China vehemently asserted its claims to this area and areas south of the McMahon line in the N.E.F.A. along its border. $^{84}$

In 1959 after China claimed these contested areas in the Aksai Chin Plain and N.E.F.A., two events occurred, which set the conditions for a military confrontation. First, a rebellion in early 1959 in north-eastern Tibet against Chinese occupation spread into central and southern Tibet, resulting in clashes between PLA soldiers and Tibetan fighters. This resulted in the

\footnotetext{
${ }^{84}$ Sinha and Athale, History of the Conflict with China, 1962, 4-24. D. K. Palit, War in High Himalaya: The Indian Army in Crisis, 1962 (London: Hurst, 1991), 40-45; Vivek Ahuja, "Genesis of the Sino-Indian Border Dispute: The Kongka La Incident” (diss., Auburn, 2011), 2-4. The McMahon line was the recognized boundary between India and Tibet that runs along the crest of the Himalayan mountains east from the eastern extremity of Bhutan to the tri-junction of the China-Burma-India border. This line was agreed to at the Tripartite Conference of India, Tibet and China in 1913-14. Even though the Chinese representative at this conference agreed to this line, China refused to recognize this border as it did not recognize Tibet as ever being an independent country that could sign a treaty. D. K. Palit was a brigade commander and general officer during the Sino-Indian conflict and provides an excellent account from a commander's perspective of this conflict.
} 
spiritual leader of Tibet, the Dalai Lama (Tenzin Gyatso), escaping with refugees into India in March 1959. India granted the Dalai Lama and his followers, political asylum out of sympathy for the Tibetan cause. This infuriated and threatened the Chinese government, as it appeared that India supported the Tibetan rebellion. Second, the Indian government adopted the "Forward Policy” in 1959. The Forward Policy was a directive to the military to incorporate with frontier police and establish a string of military outposts along the borders that India claimed. Although this policy was enacted in 1959, the military was not able to complete the establishment of these outposts across their border frontiers until 1961. Since the PLA already established outposts on what they recognized as their border, many of each respective country's outposts were effectively located on the flanks or rear of each other's positions. ${ }^{85}$

After the declaration of the Forward Policy, the Indian $5^{\text {th }}$ and $7^{\text {th }}$ Brigades of the $4^{\text {th }}$ Infantry Division in November 1959 were rushed from the Punjab plain in central India to the N.E.F.A. along the McMahon line. ${ }^{86}$ The brigades of the $4^{\text {th }}$ Infantry Division had not trained in or were equipped for mountain warfare when they transferred to the N.E.F.A.. The $5^{\text {th }}$ Brigade was given the mission of defending the less threatened border in the Surbansiri, Siang, and Lohit Frontiers. The $7^{\text {th }}$ Brigade was given the primary mission of defending the Kameng Frontier, with a secondary mission of defending the Tawang salient. The Kameng Frontier is an area approximately half the size of New Jersey and is dominated by a series of ridges and mountains that rise above 16,000 feet (approximately 5,000 m). There are fast flowing rivers, the principal being the Nyamjang Chu and Tawang Chu that are in deep gorges and are not generally fordable due to the fast current or sheer walls on either side of the river. ${ }^{87}$ The Kameng Frontier was the

\footnotetext{
${ }^{85}$ Sinha and Athale, History of the Conflict with China, 1962, 28-32: Neville Maxwell, India's China War (Garden City, NY: Anchor Books, 1972), 200-205.

${ }^{86}$ London Times, The Times Atlas of the World (New York: Times Books, 1999), 28. The elevation in the Punjab plain is less than 3,200 feet (approximately 1,000 meters) compared to the Chinese border areas, which can rise to over 15,000 feet (approximately 4,600 meters).

${ }^{87}$ Sinha and Athale, History of the Conflict with China, 1962, 13-14.
} 


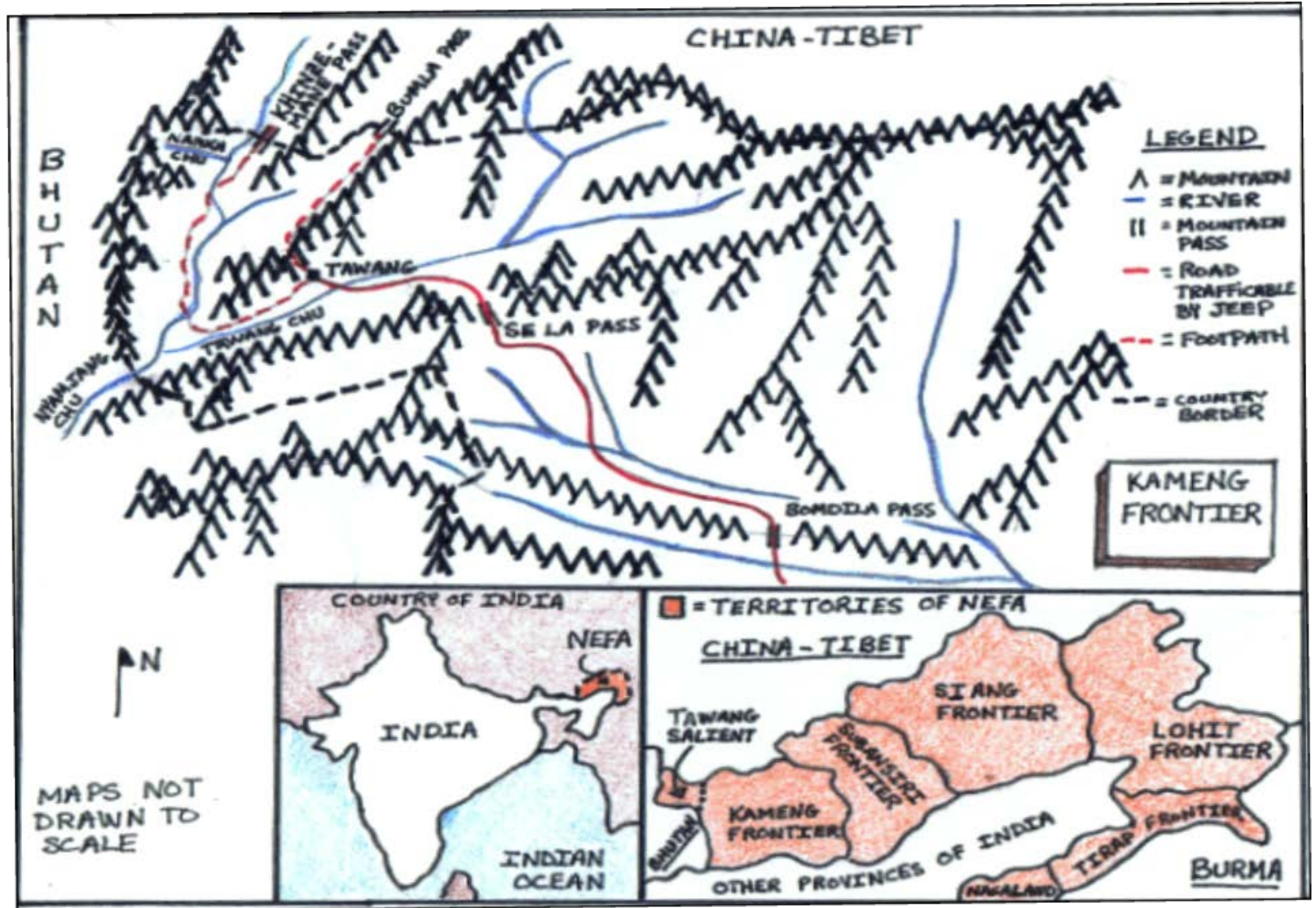

most threatened part of the border as it was the only route in N.E.F.A. that linked Tibet and India.

(Figure 5) ${ }^{88}$ Consequently, this was where the majority of Tibetan refugees crossed the Indian border.

Figure 5. N.E.F.A . and the Kameng Frontier - 1962 Indian-China Crisis.

Source: Adapted from D. K. Palit, War in High Himalaya: The Indian Army in Crisis, 1962 (London: Hurst, 1991), 202; GlobalSecurity.org, “Indian Maps,” China-India Border Eastern Sector, http://www.globalsecurity.org/military/world/india /images/map-india-china-eastern-sector-1988.jpg (accessed March 13, 2014).

In 1962 the Indian governmental leadership transformed a political dispute over territory into a militarization of their borders. India attempted to establish positions to the flanks and rear of PLA outposts in order to encourage them to pull back, which resulted in numerous clashes and

${ }^{88}$ Figure 5 has been adapted and modified by the author from its original sources and has been determined by the Fort Leavenworth Copyright coordinator, Susan Fowler, not to infringe on copyrights. 
skirmishes with the PLA. The Chinese attempted to resolve the political issues through negotiation, but would not give up its claim to the Aksai Chin Plain due to its strategic value. Then on 20 October 1962 as the Soviet Union, United States, and the rest of the international community were focused on the Cuban missile crisis, China conducted a large scale coordinated attack across the contested border areas. The Chinese attacked the Kameng Frontier and $7^{\text {th }}$ Brigade’s sector with a division sized unit of infantry armed with heavy machine guns and mortars. ${ }^{89}$

The Indian $7^{\text {th }}$ Brigade of the $4^{\text {th }}$ Infantry Division was in the N.E.F.A. for almost three years before the Chinese attacked. Due to this isolation, the $7^{\text {th }}$ Brigade's soldiers developed a cocoon mentality due to the remoteness of the mountains, limited ability to visit family, and lack of interest by leaders to allow soldiers to socialize with the local population. The Indian military leadership never allowed $7^{\text {th }}$ Brigade the time to conduct mountain warfare training and only allowed them to conduct outpost and garrison duties. ${ }^{90}$

As a result, two conditions developed that would put the $7^{\text {th }}$ Brigade at a disadvantage against a Chinese attack. First, soldiers were not equipped with adequate clothing for operations in the mountains. Their uniforms were made of cotton and they wore canvas shoes, which exposed every soldier to the harsh climate effects of the Himalayas. ${ }^{91}$ Second, the leadership often established outposts in tactically and logistically unsustainable positions. Many of the

${ }^{89}$ Arthur Cohen, The Sino-Indian Border Dispute: Section 3: 1961-1962 (Washington, DC: CIA, 1964), 69. There was a lot of questions if China would have attacked, had it not been for the Cuban missile crisis. The CIA speculates that China would have attacked anyways, but seized the opportunity to attack on this date, because the Soviet Union and United States were preoccupied. This is the third of three volumes of CIA analysis about the Sino-Indian conflict that was de-classified for open source in 1997.

${ }^{90}$ Palit, War in High Himalaya: The Indian Army in Crisis, 1962, 56.

${ }^{91} 30$ Minutes: 1962, Lest We Forget, directed by Arijat Sen (Cable News Network - India Broadcasting Network, 2012), http://www.youtube.com/watch?v=r53XCVsVlfw (accessed 24 February, 2014); Palit, War in High Himalaya: The Indian Army in Crisis, 1962, 64; Army Mountain Warfare School, Military Mountaineer Course Student Handout, 44. Cotton clothing loses its insulation value when wet, which easily occurs in a mountainous environment with snow. Using cotton clothing in a cold weather environment will predispose soldiers to cocooning and susceptibility to cold weather injuries. 
outposts were located in the bottom of valleys, ceding the high ground to an attacking enemy. The outposts were located too far forward of $7^{\text {th }}$ Brigade's ability to resupply if attacked. The leadership did not understand how mountainous terrain increased consumption rates of ammunition, decreased ground movement rates, and limited air resupply which limited their ability to resupply their forward positions.

When the Chinese attacked the Kameng Frontier, they immediately overran forward outposts as they did not mutually support each other and ran out of ammunition. ${ }^{92}$ One example of how the leaders in $7^{\text {th }}$ Brigade did not understand the effects of the operational terrain in mountains occurred along the Namka Chu river valley in the north east corner of the Tawang salient. $7^{\text {th }}$ Brigade located their military outposts near the river on the valley floor, but the PLA set up their attack positions in three tiers; along the river, half-way up the mountain slope, and along the ridges overlooking the valley. By controlling all three levels of operational terrain, the PLA were able to easily overwhelm the Indian outposts.

As the PLA units attacked, Indian soldiers were either killed, captured, or hastily retreated into Bhutan or the defensive position located at the village of Tawang, deemed vital by $4^{\text {th }}$ Infantry Division leadership. Tawang held no tactical advantage of the surrounding terrain and could easily be isolated. The $7^{\text {th }}$ Brigade leadership realized after the Chinese had seized the northern passes into Tibet that they needed to abandon their plan to hold Tawang and retreat to a position they could defend, logistically resupply, and reinforce.

The $4^{\text {th }}$ Infantry Division leadership chose the Se La pass to defend. The Se Le pass was over 14,000 feet (approximately 4,300 meters) high flanked by mountain peaks on each side. The pass dominated the surrounding terrain and the 5,000 foot (approximately 1,500 meter) ascent from Tawang was very steep. Although this position seemingly was a strong defensive position the $4^{\text {th }}$ Infantry Division leadership did not understand how the effects of mountainous terrain

${ }^{92}$ Palit, War in High Himalaya: The Indian Army in Crisis, 1962, 240; Sinha and Athale, History of the Conflict with China, 1962, 119. 
would make this position untenable. The defense of this terrain would require unacclimated reinforcements from elevations more than 10,000 feet (approximately 3,200 meters) lower to fight at high altitudes. Also, it was logistically unsustainable as the line of communication was severely extended and vulnerable. Ground resupply would take seven days for a one-ton vehicle to drive from the $4^{\text {th }}$ Infantry Division supply areas to the Se Le Pass area. Aerial resupply was unreliable due to unpredictable weather at such high elevations and often not practical as the Indian transport craft could only fly as high as 15,000 feet (approximately 4,600 meters). ${ }^{93}$

The Chinese military suspended their offensive on 24 October in order to reorganize and consolidate forces after successfully accomplishing their initial tactical objectives. The Chinese Premier Chou En-Lai offered to President Nehru a forced peace, but President Nehru rejected it, as he would not accept a violation of Indian sovereignty. During this lull in fighting the Indian military not only reorganized, but changed out the $4^{\text {th }}$ Infantry Division Commander. Two newly arrived infantry brigades and the division headquarters were supposed to be positioned at the Se Le pass in defensively prepared positions. However, the newly arrived $4^{\text {th }}$ Infantry Division commander, Major General Anant Pathania, developed altitude sickness and only located one of his infantry brigades with an additional battalion in the Se Le pass. The remaining forces, to include the division commander and his staff, remained behind at the bottom of the valley south of the Se La pass in unprepared defensive positions. As a result the $4^{\text {th }}$ Infantry Division's combat power was dispersed, more easily isolated, and the division commander suffered from a lack of situational awareness due to his inopportune altitude sickness. ${ }^{94}$

The PLA renewed their offensive across the Ladakh and N.E.F.A. regions on 17 November. The PLA bypassed and isolated the Se Le pass, whereby the $4^{\text {th }}$ Infantry Division's

\footnotetext{
${ }^{93}$ Maxwell, India's China War, 392-396; Sinha and Athale, History of the Conflict with China, 1962, 346-347.

${ }^{94}$ Palit, War in High Himalaya: The Indian Army in Crisis, 1962, 306-307.
} 
defensive fortress was cut off from their line of communication. ${ }^{95}$ The $4^{\text {th }}$ Infantry Division and its units abandoned their positions around the Se Le pass due to their inability to maintain their operational reach and maintain unit cohesion in the face of hardship. After bypassing the Se Le pass, the PLA continued to rout the $4^{\text {th }}$ Infantry Division's units. The PLA stopped their offensive on 21 November 1962 once they had seized all of the contested territory in both the N.E.F.A. and Aksai Chin Plain.

There were many contributing factors to the failure of the $4^{\text {th }}$ Infantry Division's and $7^{\text {th }}$ Brigade’s defense of the Kameng Frontier, but the most critical was the lack of mountain warfare training leaders and soldiers had. ${ }^{96}$ This was echoed by the 1962 Indian Director of Intelligence, B.N. Mullik when he recounted his thoughts of the PLA's attacks in the vicinity of the Se Le pass, “I anticipated the PLA’s movements, but I was doubtful if we would be able to neutralize them with any degree of success. Our newly deployed troops were neither physically nor mentally attuned to high altitude operations." ${ }^{\text {97 }} 7^{\text {th }}$ Brigade was not equipped for mountain warfare as they did not have adequate personal winter gear, which exposed their soldiers to the harsh conditions of the mountainous environment. The Indian military leadership across all echelons of command did not understand tactical, operational, and logistical considerations in a mountainous environment, which caused them to locate units in tactically disadvantageous positions. Unit cohesion and esprit de corps suffered due to the pro-longed isolation of troops in a mountainous environment, which caused lack of situational awareness and a willingness to retreat in the face of adversity. The Indian military’s experience in the Kameng Frontier in 1962

${ }^{95}$ Sinha and Athale, History of the Conflict with China, 1962, 164-167.

${ }^{96}$ Sinha and Athale, History of the Conflict with China, 1962, 356-360. Another key principle factor that contributed to the Indian military's failure is the government's decision to not allow the use of attack aircraft during the crisis. This decision was made based on the worries that the Chinese would bomb large populated areas and cause mass panic. This concern by the Indian governmental leadership was based on their experiences in the Second World War with Japanese bombing raids in Calcutta.

\footnotetext{
${ }^{97}$ Palit, War in High Himalaya: The Indian Army in Crisis, 1962, 291.
} 
provides an example of how a sudden conflict in a mountainous environment with units not trained in mountain warfare can lead to catastrophic failure.

\section{COUNTERARGUMENTS}

There are two primary counter arguments against the concept of organizing and equipping an active duty unit for mountain warfare. First, the US Army does not need to have mountain warfare trained units, because the US Army has been fighting successfully in the mountainous country of Afghanistan since 2001 with general purpose units. Second, if the US Army were to organize a unit specialized for mountain warfare, the US Army needs to also organize units for jungle and desert terrain, which it does not have adequate resources to implement. Although these are seemingly both valid concerns, they do not justify the current risk the United States takes by not organizing units for mountain warfare.

Since 2001 the US Army has been in Afghanistan fighting a counterinsurgency with general purpose brigade combat teams, which has been focused on the population and where the population lives. ${ }^{98}$ The majority of the population lives in the first level of operational terrain, where being trained in mountain warfare does not necessarily give an advantage. However, when the US Army has had to fight in direct action in the second and third operational levels of mountainous terrain, Army units have often fought at a disadvantage because of poor decisions by unit leadership at all echelons of command. Had the unit leadership been trained in mountain warfare, their respective units would have been able to use mountainous terrain to their advantage. This has been evidenced by previous Afghanistan battles in the Shar-i Kot Valley during Operation Anaconda in 2001, near the village of Wanat in 2008, and at Combat Outpost Keating in 2011. The lack of understanding in soldier acclimatization, location of units in relation to operational levels of terrain, and the effect of mountainous terrain on operational reach

${ }^{98}$ Department of the Army, Field Manual 3-24, Counterinsurgency (Washington, DC: HQ Department of the Army, 2006), 1-28. Counterinsurgency is a struggle for a population's support. The protection, welfare, and support of the people are vital to success. Gaining and maintaining that support is a formidable challenge. Achieving these aims requires synchronizing the efforts of many nonmilitary and host nation agencies in a comprehensive approach. 
while a unit is in enemy contact are common themes found in each of these battles. Lester Grau, a research director for the US Army Foreign Military Studies Office at Fort Leavenworth, Kansas concludes in his analysis of Operation Anaconda in December 2001 that effective combat in Afghanistan requires units that are well trained in mountain combat and acclimated for the altitude. Simply driving around valleys and allowing the enemy sanctuary within the mountains of Afghanistan does not constitute a recipe for success. ${ }^{99}$

Although one could argue that it would be prudent to have units organized specifically for jungle or desert warfare too, this type of warfare is not as important as having units organized in mountain warfare. This is because combat in mountainous terrain is more likely to occur and has more complexity than other types of terrain. ${ }^{100}$ Jungles cover less than $10 \%$ of the land surface of the earth and are isolated within equatorial latitudes. Jungle warfare is not as complex as it generally only operates in one temperature extreme, does not include altitude effects, and uses limited equipment and machinery. ${ }^{101}$ Deserts cover between 20 - 30\% of the world's land mass depending how you define desert terrain or if you include polar regions. Desert warfare is not as

${ }^{99}$ Lester W. Grau and Dodge Billingsley, Operation Anaconda: America's First Major Battle in Afghanistan (Lawrence, KS: University Press of Kansas, 2011), 351 - 355; US Army Combat Studies Institute, Wanat - Combat Action in Afghanistan 2008 (Fort Leavenworth, KS: US Army Combined Arms Center, 2010), 228-233; Jake Tapper, The Outpost: An Untold Story of American Valor (New York: Little, Brown and Co., 2012), 7-9. Grau explains that units and commanders who have reached their training potential in a mountain/cold weather environment and are fully proficient in the requisite skill sets for these environments have undergone a shift in paradigm. As a result, instead of seeing mountain and cold weather as obstacles to be overcome, they see the environment as an advantage and are able to leverage the environment to their advantage.

${ }^{100}$ Dietrich Dörner, The Logic of Failure: Recognizing and Avoiding Error in Complex Situations (Reading, MA: Addison-Wesley, 1997), 38-39. Complexity is defined as having many interdependent variables, which places greater demands on a leader's capacity to understand, visualize, and describe the environment, as well as direct actions.

${ }^{101}$ Department of the Army, Field Manual 90-5, Jungle Operations: (Washington, DC: HQ Department of the Army, 1982).1-2 to 1-8; J P. Cross, Jungle Warfare (Annapolis, MD: Naval Institute Press, 2008), 7-16. Jungle terrain can be defined as areas with dense tropical or sub-tropical growth including underbrush, trees, vines, and giant ferns and is generally categorized into three types; primary (canopy), secondary (tangled vegetation), and coastal (mangrove swamps and grass). Jungle warfare can be simply defined when war, tactics, training, logistical support and administration have to be modified because of trees. This estimation of the amount of jungle terrain in the world is not exact, but was extrapolated from the illustration of the jungle regions of the world in FM 90-5. 
complex: as it is enemy focused and not terrain focused, does not include altitude effects unless in a mountainous environment, and is typically devoid of population centers and the considerations they require. ${ }^{102}$

\section{CONCLUSIONS}

With the likelihood that future conflicts will include mountainous terrain due to the amount of mountains in the world, the US Army needs to have the cognitive intuition, called the Alpini Effect, to change its doctrine for designating active duty units to be organized, trained, and equipped for mountain warfare. Mountain warfare is complex due to the large amount of interdependent factors found in the peculiar characteristics and operational effects that mountainous terrain presents. Due to this complexity, it takes a significant amount of time for unit leadership and soldiers to learn to operate and fight effectively in a mountainous environment. The amount of time required is debatable, but it is most likely somewhere between 12-18 months based on $10^{\text {th }}$ Mountain Division's experience in the Second World War. With the US military's posture of being an expeditionary force and with the uncertainty of the time and place of future conflicts, the risk of a US Army catastrophe in a mountainous environment is high as long as the US Army continues to use general purpose units and have designated units organized and trained for mountain warfare.

This has been evidenced by literature written since 1934 from the research and combat experiences of US Army and foreign officers. The written literature from this research and these experiences overwhelming concludes that units operating in mountainous terrain need to be extensively trained in mountain warfare. As the Peruvian Lieutenant Colonel, N.E. Lindley, concluded in 1952, “Mountain warfare necessitates exceptional leaders, dedicated to mountain life, physically perfect and endowed with the spirit of initiative and sacrifice, with a fine appreciation of terrain and of the enemy, capable of evaluating the obstacles which confront them

${ }^{102}$ Department of the Army, US Army Desert Operations Handbook (Guilford: The Lyons Press, 2004), 1-2. This estimation of the amount of desert terrain is not exact and was extrapolated from the illustration of the desert regions in the world from this book. 
and estimating accurately the time required to overcome them." 103 The evolution of US Army mountain warfare doctrine and instruction since it was published in 1944 has diverged from these conclusions. Instead, current doctrine suggests that units can easily prepare for mountain operations with a singular training event. While at the same time, current US Army mountain warfare instruction for soldiers is chiefly focused on individual mountaineering techniques and neglects unit training for conducting combined arms operations in mountainous terrain.

Units that have conducted combat operations in mountainous terrain have often been successful or unsuccessful based on the amount of mountain warfare training that they have received. The $10^{\text {th }}$ Mountain Division during the Second World War in the Mediterranean theater of operations in Italy was successful due to their ability to utilize their specialized technical skills and equipment and understand the operational effects of mountainous terrain. This along with their unit cohesion and esprit de corps formed from arduous training helped the $10^{\text {th }}$ Mountain Division leverage mountainous terrain to their advantage. In contrast, the $4^{\text {th }}$ Infantry Division of the Indian Army in the Kameng Frontier in northeastern India in 1962 was unsuccessful due to their lack of equipment and lack of mountain warfare training. Had the Indian military leadership and small unit leaders been trained in mountain warfare, they would have understood the peculiar characteristics and operational effects of mountainous terrain and not made decisions that put their units in tactically and logistically unsustainable positions. As a result the unit cohesion and esprit de corps suffered in an isolated environment causing many units to retreat or flee in the face of opposition or hardship.

\section{RECOMMENDATIONS}

In order to organize and train units for mountain warfare, the US Army leadership first needs to have an Alpini Effect moment and recognize the need to designate active duty units to be organized and trained for mountain warfare. Once this occurs, the US Army needs to change its

${ }^{103}$ N.E. Lindley, "Offensive Operations in Mountainous Terrain" (Analytical Study, Fort Leavenworth, KS, 1952) 11-12. 
mountain warfare doctrine, designate active duty units to be organized for mountain warfare, adjust their respective modified table of organization and equipment (MTOE), increase the capacity for individuals to train at US Army mountaineering courses and establish the capability for unit training in a mountainous environment. ${ }^{104}$ Each of these five recommendations should be done sequentially, because if doctrine does not change; issued equipment will only be used based on the prerogatives of current unit commanders. As a result, the expertise base and 'mountain culture’ will never be built and units will not be prepared for mountain warfare.

First, US Army doctrine for mountain warfare needs to change in two ways. Field Manual 3.97.6 Mountain Operations (2000) should be renamed Mountain Warfare, in order to reflect the change of mindset of operating in mountains to conducting warfare in mountains. Doctrine needs to be updated and reflect the concept that units that conduct operations in level two and three operational terrain need to be completely reorganized, trained, and equipped for such operations.

Second, units within the US Army need to be designated to be organized for mountain warfare. It would be best to designate a light infantry division within the US Army to be organized for mountain warfare, similar to how the $82^{\text {nd }}$ Airborne Division is for airborne delivery of troops or the $101^{\text {st }}$ Airborne Division is focused on helicopter air assaults. A division sized unit is the best unit to be organized for mountain warfare as a Corps would be too big to effectively concentrate on training and a brigade combat team would not include the entire spectrum of combined arms to include helicopters and sustainment forces. It is seldom that brigade combat teams are simply deployed without some sort of divisional staff and leadership, which would require that the divisional leadership also understand mountain warfare.

Third, the US Army needs to adjust the designated units' MTOE. Skill identifiers for level one and two mountaineers should be identified for each respective unit, so that there is justification for individuals to attend the basic and advanced military mountaineering courses as

${ }^{104}$ Modified Table of Organization and Equipment (MTOE) is the authorization document that describes the amount, type, and specialty of personnel and equipment and its organization to have a specified capability to accomplish a specified mission. 
well as to provide a need to fund and conduct these courses. Mountaineering equipment and a mule pack animal contingent should be added to the equipment and organization authorizations. The mule pack animal contingent would not necessarily need to be deployable, but be able to be used for training. The mountaineering equipment and mule pack animals would facilitate unit maneuver and sustainment in mountainous terrain.

Fourth, US Army mountain warfare schools need to expand their capacity for training individuals in mountaineering skills. Currently, the US Army Mountain Warfare School in Jericho, Vermont and Northern Warfare Training Center in Black Rapids, Alaska conduct the basic military mountaineering course. The US Army Mountain Warfare School normally conducts eight classes each year, but only 15 seats per class are allocated for active duty army personnel, while the rest are for individuals from the National Guard $86^{\text {th }}$ Infantry Brigade Combat Team (Mountain). The Northern Warfare Training Center conducts only three basic mountaineering courses per year in the summer months with 48 seats per class, due to the fact that they focus on arctic survival courses in colder months. This only allows for a maximum capacity of 264 possible graduates for active duty soldiers in basic military mountaineering per year, which needs to be increased once units are designated to be organized and trained for mountain warfare. ${ }^{105}$

Finally, the US Army would also need to build the capability to train units in a mountainous environment. This can be established by creating a mountain training center that has the capacity in time, space, expertise, and personnel to train units across all war fighting functions in mountain warfare. The US Army should look at its former mountain training center

${ }^{105}$ United States Army, “ATTRS Course Catalog,” Army Training Requirements and Resources System, https://www.atrrs.army.mil/atrrscc/search.aspx (accessed March 15, 2014). The figures used for class sizes were determined by searching class dates for fiscal year 2014 for the basic military mountaineering course at AMWS and NWTC. The amount of classes conducted by AMWS, does not include the course they conduct at Dahlonega, Georgia for the US Army Ranger School to certify instructors for the mountain phase of Ranger School. The amount of active duty seats allocated for active duty at AMWS in Vermont is based on the author's knowledge from professional experience 
at Camp Carson from 1942-1944 and the US Marine Corps Mountain Warfare Training Center at Bridgeport, California for concepts on how to establish this capacity. If a division was to be designated as requiring training for mountain warfare, it would be sufficient if the mountain warfare center was able to handle a battalion task-force size element. Both the Army Mountain Warfare School and Northern Warfare Training Center have the land capacity to handle this if properly resourced. ${ }^{106}$

When the US Army acknowledges it has made the cognitive leap of the Alpini Effect, changes its doctrine, designates units to be trained in mountain warfare, organizes and equips those units, increases its mountaineering instructional capacity, and establishes a mountain training center, the US Army will be able to effectively fight in future conflicts in mountainous terrain. This will deny future adversaries terrain that it would otherwise utilize to hide or operate from to attack US interests. Consequently, the US Army would be able to provide lower risk strategic options to combatant commanders in the post Global War on Terrorism era.

${ }^{106}$ This is based on the author's personal experience at each training center as well as analyzing military maps of each military reservation. 
Table 1: United States Army Doctrine for Training Units for Mountain Warfare since 1941

\begin{tabular}{|c|c|c|}
\hline Source & Year & US Military Doctrine for Training Mountain Warfare \\
\hline $\begin{array}{l}\text { Study } \\
\text { Number } \\
23\end{array}$ & 1941 & $\begin{array}{l}\text { A division organization that has the dual mission of testing the organization and } \\
\text { equipment best suited to the employment of a division in high mountain warfare and the } \\
\text { attainment of combat efficiency for operations in such terrain. It was to be trained to } \\
\text { operate primarily in mountains and primitive terrain where road nets were poor or } \\
\text { nonexistent and under adverse and extreme weather conditions. }\end{array}$ \\
\hline FM 70-10 & 1944 & $\begin{array}{l}\text { The organization of the standard infantry division is suitable for operations in low } \\
\text { mountain terrain. Only minor modifications will be required to fit a specific situation. } \\
\text { These usually take the form of addition of pack transportation and elimination of } \\
\text { vehicles and weapons not suitable for the terrain. Complete reorganization and } \\
\text { specialized technical training, as well as the use of special clothing and equipment, will } \\
\text { be required for operations in alpine terrain. }\end{array}$ \\
\hline FM 70-10 & 1947 & $\begin{array}{l}\text { The organization of the standard infantry division is suitable for operations in } \\
\text { low mountain terrain. Only minor modifications will be required to fit a specific } \\
\text { situation. These usually take the form of addition of pack transportation and elimination } \\
\text { of vehicles and weapons not suitable for the terrain. Reorganization and specialized } \\
\text { technical training as well as the use of special clothing and equipment, will be required } \\
\text { for operations in alpine terrain. }\end{array}$ \\
\hline FM 31-72 & 1959 & $\begin{array}{l}\text { The organization of the infantry and airborne infantry division is suitable for operations } \\
\text { in mountain terrain. Only minor modifications will be required to fit a specific situation. } \\
\text { These usually take the form of additional emphasis on resupply and movement of small } \\
\text { units by army aircraft and elimination of vehicles and weapons not suitable to the } \\
\text { terrain. In alpine terrain, specialized technical training and the use of special clothing } \\
\text { and equipment will be required for operations. }\end{array}$ \\
\hline FM 31-72 & 1964 & $\begin{array}{l}\text { The organization of the infantry division is suitable for operations in mountainous areas. } \\
\text { Modifications will be required to fit specific situations. Normally these will take the } \\
\text { form of additional emphasis on resupply and elimination of vehicles and weapons not } \\
\text { suitable for the terrain. Emphasis must be placed on minimizing the load of the } \\
\text { individual soldier in order to maintain adequate foot mobility at increasing altitudes. } \\
\text { The airborne and the air assault divisions because of training and light equipment are } \\
\text { ideally suited for mountain operations. }\end{array}$ \\
\hline FM 31-72 & 1980 & $\begin{array}{l}\text { Mountain operations require, among other things, special equipment, special training } \\
\text { and acclimatization, and a high degree of self-discipline if operations are to succeed. }\end{array}$ \\
\hline FM 3-97.6 & 2000 & $\begin{array}{l}\text { Army units do not routinely train for operations in mountainous environment. Therefore } \\
\text { commanders and trainers at all levels should use US Army field manuals when } \\
\text { preparing to conduct operations in mountainous terrain. }\end{array}$ \\
\hline
\end{tabular}

Sources: Data from Thomas Govan, Training for Mountain and Winter Warfare: Study Number 23 (Washington DC: HQ Army Ground Forces, 1946), 12; War Department, Field Manual 70-10, Mountain Operations (Washington DC: US Armed Forces War Department, 1944), 1-2; War Department, Field Manual 70-10, Mountain Operations (Washington DC: US Armed Forces War Department, 1947), 1-2; Department of the Army, Field Manual 31-72, Mountain Operations (Washington DC: US Department of the Army, 1959), 3; Department of the Army, Field Manual 31-72, Mountain Operations (Washington DC: Department of the Army, 1964), 2; Department of the Army, Field Manual 90-6, Mountain Operations (Washington DC: US Department of the Army, 1980), i; Department of the Army, Field Manual 3-97.6, Mountain Operations (Washington DC: Department of the Army, 2000), v. 
Table 2: Conclusions from Research about Trained Units in Mountain Warfare since 1944

\begin{tabular}{|c|c|c|c|}
\hline Year & Author & $\begin{array}{l}\text { Nationality } \\
\text { / Job }\end{array}$ & Conclusion in regards to Mountain Warfare Trained Units \\
\hline 1947 & $\begin{array}{l}\text { Lieutenant Colonel } \\
\text { A. Romero }\end{array}$ & $\begin{array}{l}\text { Peru / } \\
\text { Logistics }\end{array}$ & $\begin{array}{l}\text { When the Liberator, Simon Bolivar decided to bring about the } \\
\text { battles that were to liberate Peru and assure the independence of the } \\
\text { South American continent, he chose for his battle ground the } \\
\text { mountains and placed emphasis on two things. The first being the } \\
\text { training of the army, for which he chose appropriate terrain in the } \\
\text { Department of Acaha where he carried out intensive training for } \\
\text { several months. }\end{array}$ \\
\hline 1947 & Major Lu Fu Ning & China & $\begin{array}{l}\text { A mountain combat command should have special equipment and } \\
\text { training. Self-sufficiency, mobility and flexibility are necessary } \\
\text { characteristics }\end{array}$ \\
\hline 1948 & $\begin{array}{l}\text { Captain Thurman } \\
\text { Brandon }\end{array}$ & $\begin{array}{l}\text { US / } \\
\text { Infantry }\end{array}$ & $\begin{array}{l}\text { Troops, if at all possible, should be trained in the kind of terrain in } \\
\text { which it is expected that they will be employed }\end{array}$ \\
\hline 1950 & $\begin{array}{l}\text { Lieutenant Colonel } \\
\text { Henry Frankel }\end{array}$ & US / Armor & $\begin{array}{l}\text { No armored unit should operate in mountainous country without } \\
\text { prior training: which would condition the troops to mountain } \\
\text { combat. }\end{array}$ \\
\hline 1952 & $\begin{array}{l}\text { Lieutenant Colonel } \\
\text { N.E. Lindley }\end{array}$ & Peru & $\begin{array}{l}\text { Mountain Warfare necessitates exceptional leaders, dedicated to } \\
\text { mountain life, physically perfect and endowed with the spirit of } \\
\text { initiative and sacrifice, with a fine appreciation of terrain and of the } \\
\text { enemy, capable of evaluating the obstacles which confront them and } \\
\text { estimating accurately the time required to overcome them. }\end{array}$ \\
\hline 1974 & $\begin{array}{l}\text { Major Melvin } \\
\text { Richmond Jr. }\end{array}$ & US & $\begin{array}{l}\text { Historical precedence has been established by the 10th Mountain } \\
\text { Division In world War I1 with regards to the value training in } \\
\text { mountains had to the success of their combat mission. Also, the } \\
\text { training they and the Mountain Warfare Training Center conducted } \\
\text { for other divisions of the Army contributed significantly to the } \\
\text { success of these divisions. }\end{array}$ \\
\hline 1994 & Major Dana Pittard & US, Armor & $\begin{array}{l}\text { In a future crisis in a mountainous region, the US is likely to deploy } \\
\text { heavy forces. As such, heavy forces must be prepared to fight and } \\
\text { win upon arrival. }\end{array}$ \\
\hline 2003 & $\begin{array}{l}\text { Major Muhammad } \\
\text { Asim Malik }\end{array}$ & Pakistan & Maintain operationally ready mountain troops. \\
\hline 2008 & $\begin{array}{l}\text { Lieutenant Colonel } \\
\text { Scott Pierce }\end{array}$ & US & $\begin{array}{l}\text { Mountain and cold weather warfare has a long history and that } \\
\text { history clearly demonstrates that those who ignore it are doomed to } \\
\text { fail when fate places them in such an environment. The US does not } \\
\text { have the ability to efficiently and effectively wage war in mountains } \\
\text { or cold weather against a competent, acclimatized enemy. }\end{array}$ \\
\hline
\end{tabular}

Sources: Data from A. Romero, "Logistics in the Mountainous Terrain of Peru" (Analytical Study, Fort Leavenworth, KS, 1947); Lu Fu-Ning, "A Mountain Operation in the Sino-Japanese War (1944)" (Historical Research, Fort Leavenworth, KS, 1947); Thurman Brandon, "The North Apennines (Gothic Line) Campaign: August 1944 - April 1945" (Master's Thesis, Ft. Benning, GA, Advanced Infantry Officers Course, 1946); Frankel Henry, "Armor in Mountain Warfare" (Research Report, Fort Knox, KY, May 1950); N.E. Lindley, "Offensive Operations in Mountainous Terrain" (Analytical Study, Fort Leavenworth, KS, 1952); Melvin Richmond, "Combat Operations in Mountainous Terrain: Are United States Army Light Infantry Divisions Preparing Properly?" (Master's Thesis, Fort Leavenworth, KS, 1974); Dana Pittard, "The Heavy Battalion Task Force in Mountainous Terrain: Are Current Tactics, Techniques, and Procedures Adequate?" (Monograph, Fort Leavenworth, KS, 1994); Muhammad Malik, "Mountain Warfare: The Need for Specialist Training" (Master’s Thesis, Fort Leavenworth, KS, 2003); Scott Pierce, "Mountain and Cold Weather War Fighting: Critical Capability for the 21st Century" (Monograph, Fort Leavenworth, KS, 2008). 


\begin{tabular}{|c|c|}
\hline $\begin{array}{c}\text { Countries with Mountainous Borders } \\
\text { (132 countries) }\end{array}$ & $\begin{array}{l}\text { Countries without Mountainous Borders } \\
\text { (22 non-island \& } 39 \text { island countries) }\end{array}$ \\
\hline $\begin{array}{l}\text { Afghanistan, Albania, Algeria, Andorra, Angola, } \\
\text { Argentina, Armenia, Austria, Azerbaijan, Bangladesh, } \\
\text { Belize, Bhutan, Bolivia, Bosnia and Herzegovina, } \\
\text { Botswana, Brazil, Bulgaria, Burkina Faso, Burundi, } \\
\text { Cambodia, Cameroon, Canada, Central African } \\
\text { Republic, Chad, Chile, China, Colombia, Costa Rica, } \\
\text { Cote D’Ivoire (Ivory Coast), Croatia, Czech Republic, } \\
\text { Democratic Republic of Congo, Djibouti, Dominican } \\
\text { Republic, East Timor, Ecuador, Egypt, El Salvador, } \\
\text { Equatorial Guinea, Eritrea, Ethiopia, Finland, France, } \\
\text { Gabon, Georgia, Germany, Greece, Guatemala, } \\
\text { Guinea, Guyana, Haiti, Honduras, Hungary, India, } \\
\text { Indonesia, Iran, Iraq, Ireland, Israel, Italy, Jordan, } \\
\text { Kazakhstan, Kenya, Kyrgyzstan, Laos, Lebanon, } \\
\text { Lesotho, Liberia, Libya, Liechtenstein, Macedonia, } \\
\text { Malawi, Malaysia, Mali, Mexico, Mongolia, } \\
\text { Montenegro, Morocco, Mozambique, Myanmar, } \\
\text { Namibia, Nepal, Nicaragua, Niger, Nigeria, North } \\
\text { Korea, Norway, Oman, Pakistan, Panama, Papua New } \\
\text { Guinea, Paraguay, Peru, Poland, Portugal, Romania, } \\
\text { Russia, Rwanda, San Marino, Saudi Arabia, Serbia, } \\
\text { Sierra Leone, Slovakia, Slovenia, Somalia, South } \\
\text { Africa, South Korea, South Sudan, Spain, Sudan, } \\
\text { Suriname, Swaziland, Sweden, Switzerland, Syria, } \\
\text { Tanzania, Tajikistan, Thailand, Togo, Tunisia, } \\
\text { Turkey, Turkmenistan, Uganda, Ukraine, United Arab } \\
\text { Emirates, United States, Uzbekistan, Venezuela, } \\
\text { Vietnam, Yemen, Zambia, Zimbabwe }\end{array}$ & $\begin{array}{l}\text { Bahrain, Belarus, Belgium, Benin, Denmark, } \\
\text { Estonia, Gambia, Ghana, Guinea Bissau, } \\
\text { Kuwait, Latvia, Lithuania, Luxembourg, } \\
\text { Mauritania, Moldova, Monaco, Netherlands, } \\
\text { Qatar, Senegal, Singapore, United Kingdom, } \\
\text { Uruguay } \\
\text { Island Nations: } \\
\text { Antigua and Barbuda, Australia, Bahamas, } \\
\text { Barbados, Brunei, Cape Verde, Comoros, } \\
\text { Cuba, Cyprus, Dominica, Fiji, Grenada, } \\
\text { Iceland, Jamaica, Japan, Kiribati, Madagascar, } \\
\text { Maldives, Malta, Marshall Islands, Mauritius, } \\
\text { Micronesia, Nauru, New Zealand, Palau, } \\
\text { Philippines, Qatar, Saint Kitts and Nevis, } \\
\text { Saint Lucia, Saint Vincent and the } \\
\text { Grenadines, Samoa, Sao Tome and Principe, } \\
\text { Seychelles, Solomon Islands, Sri Lanka, } \\
\text { Tonga, Trinidad and Tobago, Tuvalu, } \\
\text { Vanuatu }\end{array}$ \\
\hline
\end{tabular}

Sources: Data from US National Geospatial Intelligence Agency, "Countries in the World with Mountainous Borders” (Analytical Research, St. Louis, MO, 20 January 2014): US Army Geospatial Center, "Country Borders with and Without Mountainous Borders” (Analytical Research, Fort Belvoir, VA, 25 February 2014). 
Table 4: Comparison of Weather Effects

\begin{tabular}{|c|c|c|}
\hline $\begin{array}{l}\text { Typical Weather } \\
\text { Conditions }\end{array}$ & Effects in non-mountainous terrain & Added effects from mountainous terrain \\
\hline Sunshine & $\begin{array}{ll}\text { - } & \text { Sunburn } \\
\text { - } & \text { Snow Blindness } \\
\text { - } & \text { Temperature difference } \\
\text { between sun and shade }\end{array}$ & $\begin{array}{l}\text { - Increased risk of sunburn and snow } \\
\text { blindness } \\
\text { - } \quad \text { Extreme temperature variations } \\
\text { between sun and shade } \\
\text { - Avalanches / Rock fall }\end{array}$ \\
\hline Wind & - Windchill & $\begin{array}{ll}\text { - } & \begin{array}{l}\text { Increased risk and severity of } \\
\text { windchill }\end{array} \\
\text { - } & \begin{array}{l}\text { Blowing debris or driven snow } \\
\text { causing reduced visibility }\end{array} \\
\text { - } & \text { Avalanches } \\
\text { - } & \begin{array}{l}\text { Increase in force and speed of wind } \\
\text { gusts }\end{array} \\
\end{array}$ \\
\hline Rain & $\begin{array}{l}\text { - } \quad \text { Reduced visibility } \\
\text { - } \quad \text { Cooler Temperatures }\end{array}$ & $\begin{array}{l}\text { - } \text { Landslides } \\
\text { - } \text { Flash floods } \\
\text { - Avalanches } \\
\end{array}$ \\
\hline Snow & $\begin{array}{l}\text { - } \text { Cold weather injuries } \\
\text { - } \text { Reduced mobility and } \\
\text { visibility } \\
\text { - Snow Blindness } \\
\text { - Blowing snow }\end{array}$ & $\begin{array}{l}\text { - Increased risk and severity of } \\
\text { common effects } \\
\text { - Avalanches }\end{array}$ \\
\hline Storms & $\begin{array}{ll}\text { - } & \text { Rain/ snow } \\
\text { - } & \text { Reduced visibility } \\
\text { - } & \text { Lightning } \\
\end{array}$ & 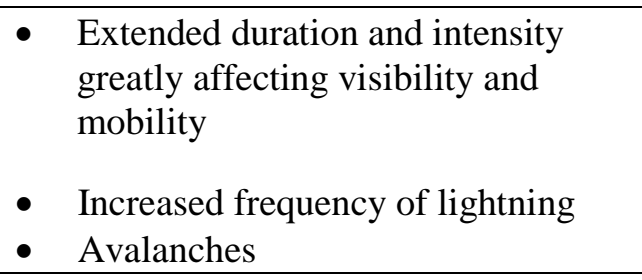 \\
\hline Fog & $\begin{array}{l}\text { - } \text { Reduced mobility / } \\
\text { visibility }\end{array}$ & - Increased frequency and duration \\
\hline Cloudiness & - $\quad$ Reduced visibility & \begin{tabular}{|l} 
- \\
$\begin{array}{l}\text { Greatly decreased visibility at higher } \\
\text { elevations }\end{array}$ \\
\end{tabular} \\
\hline
\end{tabular}

Sources: Data adapted from Department of the Army, Field Manual 3-97.6, Mountain Operations (Washington DC: Department of the Army, 2000), Page 1-7; United States Army Alaska Northern Warfare Training Center, Basic Mountaineering Course Handout (Fairbanks, AK: United States Army 
Alaska Northern Warfare Training Center, 2012), 21-50; Army Mountain Warfare School, Military Mountaineer Course Student Handout (Jericho, VT: Army Mountain Warfare School, 2013), 90-94.

\section{BIBLIOGRAPHY}

Primary Sources

$\underline{\text { Government Publications }}$

de Freycinet, C. Bulletin 1208, Number 20037 - Loi Qui Modife L'organisation Des Bataillons de Chasseurs á Pied. Paris: France, 1888.

Emmanuel II, Victor. Royal Decree 1056. Naples: Kingdom of Italy, 15 October 1872.

United States. Agreement Between the Republic of India and the People's Republic of China on Trade and Intercourse Between Tibet Region of China and India. April 24, 1954. UNTS 299, no. 4307, pt. 6 (1954).

\section{$\underline{\text { After Action Reviews }}$}

Cohen, Arthur. The Sino-Indian Border Dispute: Section 3: 1961-1962. Washington DC: CIA, 1964.

HQ 15th Army Group, G3 Section. A Military Encyclopedia, Based on Operations in the Italian Campaign 1943-1945. Italy: HQ 15th Army Group, Unknown.

US Army Combat Studies Institute. Wanat - Combat Action in Afghanistan 2008. Fort Leavenworth: US Army Combined Arms Center, 2010.

War Department. "History of Planning Division: The Mediterranean Campaign." After action review of planning operations of WWII, Washington DC, 1945.

\section{Books, Essays and Thesis' based on Personal Experiences}

Brandon, Thurman. "The North Apennines (Gothic Line) Campaign: August 1944 - April 1945." Master's Thesis, Ft. Benning Advanced Infantry Officers Course, 1946.

Cole, Robert. "The Attack on the Gothic Line." Personal Experience of a Battalion Commander, Fort Leavenworth, 1947.

Hampton, Henry. The Riva Ridge Operation: Report On the Mancinello-Campiano Ridge Operation of the 1st Battalion, 86th Mountain Infantry. Udine: Headquarters 86th Infantry Regiment, 1945.

Palit, D. K. War in High Himalaya: The Indian Army in Crisis, 1962. London: Hurst, 1991. 
Perruchetti, Giuseppe. "Saggio di Geografia Mulitare Seguito da Una Appendice Su La Difesa di Alcuni Valichi Alpini." Analytical study for the defense of Italian Alpine border, Torino, Italy, 1882.

Roschmann, Hans. Mountain Warfare: A Brief Treatise Based On Operations of 1st Mountain Division in Caucasus, August - September 1942. Germany: US Army Europe, 1954.

Secondary Sources

\section{Government Publications}

Department of the Army. Army Doctrine Reference Publication 3-0, Unified Land Operations. Washington, DC: HQ Department of the Army, 2012.

Army Regulation 95-1, Aviation Flight Regulations. Washington, DC: HQ Department of the Army, 2008.

Field Manual 1-02, Operational Terms and Graphics. Washington, DC: HQ Department of the Army, 2004.

. Field Manual 3-24, Counterinsurgency. Washington, DC: HQ Department of the Army, 2006. 2010

Field Manual 3-90.6, Brigade Combat Team. Washington, DC: HQ Department of the Army,

. Field Manual 3-97.61, Military Mountaineering. Washington, DC: HQ Department of the Army, 2002.

. Field Manual 3-97.6, Mountain Operations. Washington, DC: HQ Department of the Army, 2000 .

. Field Manual 31-72, Mountain Operations. Washington, DC: HQ Department of the Army, 1964.

Field Manual 31-72, Mountain Operations. Washington, DC: US HQ Department of the Army, 1959.

. Field Manual 90-5, Jungle Operations. Washington, DC: HQ Department of the Army, 1982.

. Technical Manual 1-1520-240-10, Technical Manual Operator's Manual for Army CH47-D

Helicopter. Washington, DC: HQ Department of the Army, 2003.

. US Army Desert Operations Handbook. Guilford: The Lyons Press, 2004.

Govan, Thomas. Training for Mountain and Winter Warfare: Study Number 23. Washington, DC: HQ Army Ground Forces, 1946.

US Army Alaska Northern Warfare Training Center. Mountain Operations Student Handout. Fairbanks, AK: United States Army Alaska Northern Warfare Training Center, 2012. 
US Army Mountain Warfare School. Military Mountaineer Course Student Handout. Jericho, VT: Army Mountain Warfare School, 2013.

US Army. Ranger Handbook: SH 21-76. Fort Benning, GA: Ranger Training Brigade, 2011.

US Director of Central Intelligence. The Sino-Indian Conflict: Outlook and Implications. Washington, DC: Central Intelligence Agency, 1962.

War Department. Field Manual 70-10, Mountain Operations. Washington, DC: United States Forces War Department, 1947.

. Field Manual 70-10, Mountain Operations. Washington, DC: United States Forces War Department, 1944.

. German Mountain Warfare. Washington, DC: Military Intelligence Division, 1944.

Wickam, General John. White Paper 1984: Light Infantry Divisions. Washington, DC: Chief of Staff of the Army, 1984.

\section{$\underline{\text { Official Histories }}$}

Blumenson, Martin. The Mediterranean Theater of Operations: Salerno to Cassino. Washington, DC: Center of Military History, 1969.

. US Army in WWII Salerno to Cassino: Mediterranean Theater of Operations. Washington, DC: Center of Military History, 2002.

Cohen, Arthur. The Sino-Indian Border Dispute: Section 3: 1961-1962. Washington, DC: CIA, 1964.

Fisher Jr., Ernest. US Army in WWII Mediterranean Theater of Operations: Cassino to the Alps. Washington, DC: Center of Military History, 1977.

Imbrie, John. Chronology of the 10th Mountain Division in World War II: 6 January 1940 - 30 November 1945. Lakewood: National Association of the 10th Mountain, 2004.

Sinha, Dr. P. B., and Colonel A. A. Athale. History of the Conflict with China, 1962. New Delhi: History Division Indian Government Ministry of Defence, 1992.

US Army. Fifth Army History 1939-1945.Washington DC: Fifth Army US Army, 1945.

\section{Books}

Alfred, Church. The Story of Nations: Carthage. London: G. P. Putnam's Sons, 1895.

Asymmetric Warfare Group. Soldier's Guide to Mountain Warfare. Fort Leavenworth, KS: Center for Army Lessons Learned, 2012.

Bird, W. D. Some Principles of Frontier Mountain Warfare. Pall Mall: Hugh Rees, 1909.

Brooks, Thomas R. The War North of Rome, June 1944-May 1945. New York: Sarpedon, 1996. 
Chandler, David G. Napoleon's Marshals. New York: Macmillan, 1987.

Clausewitz, Carl von. On War. Translated by Michael Howard and Peter Paret. Princeton, NJ: Princeton University Press, 1976.

Cross, J. P. Jungle Warfare. Annapolis, MD: Naval Institute Press, 2008.

Dörner, Dietrich. The Logic of Failure: Recognizing and Avoiding Error in Complex Situations. Reading, MA: Addison-Wesley, 1997.

Gober, Donald. Cassino: Battlebook 15-A. Fort Leavenworth, KS: US Army Combat Studies Institute, 1984.

Grau, Lester W., and Dodge Billingsley. Operation Anaconda: America's First Major Battle in Afghanistan. Lawrence, KS: University Press of Kansas, 2011.

Grau, Lester, and Charles Bartles. Mountain Warfare and Other Lofty Problems: Foreign Perspectives On High-Altitude Combat. Fort Leavenworth, KS: Foreign Military Studies Office, 2011.

Hamilton, Hope. Sacrifice on the Steppe: The Italian Alpine Corps in the Stalingrad Campaign, 19421943. Philadelphia, PA: Casemate, 2011.

Hunt, William. History of Italy. New York City: Henry Holt and Company, 1875.

Jomini, Antoine. The Art of War. Translated by G. H. Mendell and W. P. Craighill. Philadelphia: J. B. Lippincott and Company, 1862.

Lichem, Heinz. Gebirgskrieg 1915-1918: Die Dolomiten Front. n.p.: Athesia, 1988. . Gebirgskrieg 1915-1918: Karnische Und Julische Alpen. n.p.: Athesia, 1989. . Gebirgskrieg 1915-1918: Ortler, Adamello, Gardasee. n.p.: Athesia, 1980.

MacKenzie, D. B. Mountain Warfare on the Sand Model. Aldershot: Gale and Polden, n.d.

Mascarenhas de Moraes, Marshall J.B. The Brazilian Expeditionary Force by Its Commander. Washington, DC: Center of Military History, 1965.

Matloff, Marice. Command Decisions: The 90-Division Gamble. Washington, DC: Center of Military History, 1960.

Maxwell, Neville India's China War. Garden City, NY: Anchor Books, 1972.

Pietro, Orsi. The Story of the Nations: Modern Italy: 1748-1898. New York City: G. P. Putnam's Sons, 1900.

Robert, Baumann. Russian-Soviet Unconventional Wars in the Caucasus, Central Asia, and Afghanistan. Fort Leavenworth, KS: US Army Combat Studies Institute, 1993. 
Shelton, Peter. Climb to Conquer: The Untold Story of World War II's 10th Mountain Division Ski Troops. New York: Scribner, 2003.

Tapper, Jake. The Outpost: An Untold Story of American Valor. New York: Little, Brown and Co., 2012.

Times, London. The Times Atlas of the World. New York: Times Books, 1999.

Wawro, Geoffrey. The Franco-Prussian War: the German Conquest of France in 1870-1871. New York: Cambridge University Press, 2003.

\section{Monographs, MMAS Thesis, and Analytical Research}

Brown, Homer. "Operations on the Italian Front in 1917, Paying Particular Attention to the Caporetto Disaster and the Retreat to the Piave." Historical Research, Command and General Staff School, Fort Leavenworth, KS, 1934.

Clarke, Edwin. "Enhancing the US Special Operations Mountaineering Program." Master’s Thesis, Naval Post Graduate School, Monterrey, CA, June 2012.

Frankel, Henry. "Armor in Mountain Warfare." Research Report, Fort Knox, KY, May 1950.

Fu-Ning, Lu. "A Mountain Operation in the Sino-Japanese War (1944)." Historical Research, Command and General Staff College, Fort Leavenworth, KS, 1947.

Jackson, Joseph. "Howitzers On High Ground: Considerations for Artillery Employment in Southwest Asia." Monograph, School of Advanced Military Studies, Fort Leavenworth, KS, 2009.

Lindley, N.E. "Offensive Operations in Mountainous Terrain." Analytical Study, Command and General Staff College, Fort Leavenworth, KS 1952.

Malik, Muhammad. "Mountain Warfare: The Need for Specialist Training." Master's Thesis, Command and General Staff College, Fort Leavenworth, KS, 2003.

Merino, M. "The Influence of Logistics On the Organization of the Army Corps and the Infantry Division in Mountainous Terrain." Analytical Study, Command and General Staff College, Fort Leavenworth, KS, 1947.

Pierce, Scott. "Mountain and Cold Weather Warfighting: Critical Capability for the 21st Century." Monograph, School of Advanced Military Studies, Fort Leavenworth, KS, 2008.

Pittard, Dana. "The Heavy Battalion Task Force in Mountainous Terrain: Are Current Tactics, Techniques, and Procedures Adequate?" Monograph, School of Advanced Military Studies, Fort Leavenworth, KS, 1994.

Richmond, Melvin "Combat Operations in Mountainous Terrain: Are United States Army Light Infantry Divisions Preparing Properly." Master’s Thesis, Command and General Staff College, Fort Leavenworth, KS, 1987.

Romero, A. "Logistics in the Mountainous Terrain of Peru." Analytical Study, Command and General Staff College, Fort Leavenworth, KS, 1947. 
Stephan, Scott. "Changing the Mountain and Cold Weather Training Paradigm." Research Report, USMC Command and Staff College, Quantico, VA, 2006.

US Army Geospatial Center, "Country Borders with and Without Mountainous Borders." Analytical Research, Fort Belvoir, VA, 25 February 2014.

US National Geospatial Intelligence Agency, “Countries in the World with Mountainous Borders” Analytical Research, St. Louis, MO, 20 January 2014.

\section{$\underline{\text { Periodicals }}$}

Abitbol, Aldo. "Causes of the 1962 Sino-Indian War: A Systems Level Approach." Josef Korbel Journal of Advanced International Studies (March 2011): 74-87.

Bourbon Del Monte, G. "The Origin of Our Alpine Troops." The United Service Magazine (April September 1898): 162-72.

Edwards, J.S.A, S.P.L. Travis, and A. L. Dinmore. "Food and Nutritional Intake at High Altitudes." Nutrition and Food Science 98, no. 1 (1998): 5-10.

Knox, Gustave. "Some Aspects of Mountain Warfare." Military Review (July 1942): 57-63.

Powell, Marcus. "Mountain Operations." Military Review (January 1953): 6-15.

Russell, Eno. "Mountain Operations, a Historical Perspective." Infantry (January/February 2008): 23-26.

\section{$\underline{\text { Websites }}$}

"History of 10th Mountain Division." Fort Drum Official Website. http://www.drum.army.mil/ AboutFortDrum/Pages/hist_10thMountainHistory_lv3.aspx (accessed August 14, 2013).

"United Nations Member States." United Nations. http://www.un.org/en/members/index.shtml (accessed January 11, 2014).

Engels, Frederick. "Marx and Engels Collected Works." Marxist Internet Archive. http://www.marxists.org/archive/marx/works/cw/ (accessed November 26, 2013).

GlobalSecurity.org. "Indian Maps." China-India Border Eastern Sector. http://www.globalsecurity.org/ military/world/india/images/map-india-china-eastern-sector-1988.jpg (accessed March 13, 2014).

Richard, Galli. "Le Grande Guerra: The Italian Front 1915-1918." Avalanche. http://www.worldwar1.com/itafront/avalan.htm (accessed February 15, 2014).

Sray, John. "Mountain Warfare: The Russian Perspective." US Army Foreign Military Studies Office. Fort Leavenworth, Mar. 1994. Web. http://fmso.leavenworth.army.mil/documents/mountain.htm (accessed January 23, 2014).

US Army. "ATTRS Course Catalog." Army Training Requirements and Resources System. https://www.atrrs.army.mil/atrrscc/search.aspx (accessed March 15, 2014). 
Young, Andrew. "Distance to the Horizon." San Diego State Department of Astronomy. http://mintaka.sdsu.edu/GF/explain/atmos_refr/horizon.html (accessed January 12, 2014).

\section{$\underline{\text { Video and Lectures }}$}

30 Minutes: 1962, Lest We Forget. Directed by Arijat Sen. Cable News Network - India Broadcasting Network, 2012. http://www.youtube.com/watch?v=r53XCVsVlfw (accessed 24 February, 2014).

Prayner, William "Altitude Illness Prevention and Treatment." Lecture, US Army Northern Warfare Training Center, Black Rapids, AK, July 12, 2012.

"Mountain Leadership." Lecture, US Army Northern Warfare Training Center, Black Rapids, AK, July 12, 2012.

"Route Planning for Operations in Mountainous Terrain." Lecture, US Army Northern Warfare Training Center, Black Rapids, AK, July 12, 2012. 